\title{
ANÁLISIS DEL CONTRATO ELECTRÓNICO Y LA INFORMACIÓN PRE Y POSCONTRACTUAL EN COLOMBIA A PROPÓSITO DE LA LEGISLACIÓN COMUNITARIA Y EXTRANJERA*
}

\author{
Vladimir Monsalve Caballero"
}

Fecha de recibido: 20 de marzo de 2014

Fecha de aprobado: 19 de julio de 2014

Artículo de revisión

Forma de citación: Monsalve, V. (2015). Análisis del contrato electrónico y la información pre y poscontractual en Colombia a propósito de la legislación comunitaria y extranjera. Revista Prolegómenos. Derechos y Valores, 18, 35, 17-48.

\section{Resumen}

El presente artículo tiene por objeto analizar el panorama legal colombiano de la contratación electrónica con consumidores, en lo concerniente a la información como un supuesto básico de la etapa previa y poscontractual, desde una metodología de derecho comparado, y se determinará la suficiencia e idoneidad de la legislación nacional en contexto con el ámbito de las directivas europeas aplicables a la materia. Concluiremos, que si bien el panorama legal colombiano comienza a dar pasos sólidos en lo pertinente a la actualización con los marcos regulatorios internacionales y extranjeros que propenden por un consenso en la protección de la información del consumidor electrónico; una evaluación final de contenido positivo no es del todo satisfactoria, debido al letargo en el desarrollo legal (vía decretos y regulación económica) y la insuficiente adecuación institucional para intervenir el mercado en momentos decisivos.

\section{Palabras clave:}

Comercio electrónico, obligaciones precontractuales de información, obligaciones poscontractuales de información, estatuto de protección jurídica de los consumidores.

\footnotetext{
" Resultado de investigación del proyecto "El derecho de consumo, el nuevo derecho común del siglo XXI", adscrito al Grupo de Investigación Estudios Sociales, Políticos y Jurídicos de la Facultad de Jurisprudencia de la Universidad Autónoma del Caribe.

** Abogado egresado de la Facultad de Derecho de la Universidad Santo Tomás, seccional Bucaramanga, especialista en Derecho Comercial y Financiero. Con diploma de Estudios Avanzados en Nuevas Tendencias del Derecho Privado, máster oficial en Regulación Económica, doctor en Derecho con calificación sobresaliente cum laude de la Universidad de Salamanca, España. Profesor investigador de la Facultad de Jurisprudencia de la Universidad Autónoma del Caribe, en la ciudad de Barranquilla. Correo electrónico: vladimir.monsalve@uac.edu.co
} 


\title{
ANALYSIS OF ELECTRONIC CONTRACT AND PRE AND POST-CONTRACTUAL INFORMATION IN COLOMBIA REGARDING COMMUNITY AND FOREIGN LEGISLATION
}

\begin{abstract}
Summary
The purpose of this article is to analyze the colombian legal outlook in electronic hiring with consumers, regarding information as a basic assumption of pre and post-contractual stages, with a methodology of compared law, where competence and aptitude of national legislation will be determined, in context with the european leadership environment applicable to this subject. We will conclude that, despite the colombian legal outlook begins to take vital steps regarding update with international regulations that tend to an agreement about protection of electronic consumers information, a final evaluation of contents is not totally satisfactory because of the stagnation in legal development (through decree and economic regulations) and the insufficient institutional adaptation to intervening market in decisive moments.
\end{abstract}

\section{Key words:}

Electronic trade, pre-contractual information obligations, post-contractual information obligations, statute of legal protection for consumers.

\section{ANALISE DO CONTRATO ELETRÓNICO E A INFORMAÇÃO PRE E POSCONTRATUAL NA COLÔMBIA A PROPÓSITO DA LEGISLAÇÃO COMUNITÁRIA E EXTRANGEIRA}

\begin{abstract}
Resumo
O presente artigo tem por objeto analisar o panorama legal colombiano da contratação eletrônica com consumidores, no concernente à informação como um suposto básico da etapa previa e pôs-contratual, desde uma metodologia de direito comparado, donde será determinada a suficiência e idoneidade da legislação nacional no contexto com o âmbito das diretivas europeias aplicáveis à matéria. Concluiremos, que se bem o panorama legal colombiano começa dar passos sólidos no pertinente à atualização com os marcos regulatórios internacionais e estrangeiros que propendem por um consenso na proteção da informação do consumidor eletrônico; uma avaliação final de conteúdo positivo não é totalmente satisfatória, devido ao letargo no desenvolvimento legal (via decretos regulação económica) e a insuficiente adequação institucional para intervir no mercado nos momentos decisivos.
\end{abstract}

\section{Palavras chave:}

Comércio eletrônico, obrigações pre-contratuais de informação, obrigações pôs-contratuais de informação, estatuto de proteção jurídica dos consumidores.

\section{INTRODUCCIÓN}

Es inocultable el desarrollo al que hemos asistido en los últimos años en torno a los instrumentos, las comunicaciones y las redes electrónicas, lo que ha permitido un acceso generalizado de la sociedad a diversas fuentes de información (en otrora impensables) y por otro, al auge en la contratación virtual. Es una nueva sociedad en la que diversos paradigmas quedan atrás, y 
en la que es necesario replantear la forma de interactuar, y de concebir dentro de este nuevo escenario un rol más activo del derecho y de sus fuentes, al reconocer sin oposición, que es la información el principal recurso (activo) en la toma de decisiones sociales, comerciales y económicas en la modernidad.

En un entorno en el que la innovación, el conocimiento y la capacidad de utilizar la información son clave en la competitividad y en la organización de las empresas, se producen importantes transformaciones en las relaciones de producción y de consumo. El nuevo significado de la información y la utilización generalizada de las redes electrónicas impone notables exigencias de adaptación al ordenamiento jurídico, que van más allá de la simple actualización de sectores concretos, afectando al derecho en su conjunto, pues la inmaterialidad y la ubicuidad características de la información en el entorno digital condicionan ahora decisivamente tanto la posibilidad de establecer relaciones como la configuración de estas, así como la mayor importancia del comercio internacional de servicios y de los activos intangibles para las empresas (De Miguel, 2005).

Si bien la contratación en masa fue un fenómeno que comenzó a desplegarse tardíamente en Colombia en los años noventa, en el presente ha recibido uno de los impulsos más grandes con el avance tecnológico (si bien en los dos últimos decenios del siglo pasado se vio afectada por el modelo económico imperante que fortalecía las barreras de entrada y el direccionismo estatal; con la revolución tecnológica acaecida y con la adopción y puesta en marcha de un nuevo modelo político y económico, se dio paso a un contrato

1 Según datos del Ministerio de Tecnologías de la Información y las Comunicaciones, para marzo del 2010 el Estado calculó que Colombia tiene 22 millones de usuarios, no obstante el comercio electrónico está por consolidarse, en el 2010 se hicieron negocios en el ámbito nacional por un valor cercano a 600 millones de dólares, representando así el $2 \%$ del volumen del comercio de América Latina (Revista Enter, 27 de diciembre de 2010). masificado, despersonalizado e intangible). Con la Internet llegó, el comercio electrónico a todas las escalas (nacionales y mundiales), el desarrollo y los novedosos mercados en los que se mueven cantidades inimaginables de usuarios ${ }^{1}$, dinero, datos y bienes, que difícilmente se hubieran generado en mercados entre personas presentes.

Se trata de un auténtico mercado electrónico transnacional, que tomando como base la conexión en red de computadores, permite a los operadores económicos (productores, empresarios, intermediarios y consumidores) interactuar electrónicamente, lo que reporta ciertas ventajas con los mercados físicos tradicionales, como la mejora en la gestión de las transacciones (su mayor rapidez) y el incremento de la eficiencia empresarial (reducción de actividades físicas); favorece la adaptabilidad (al tener una amplia extensión el principio de la autonomía de la voluntad) los procedimientos de rendición de cuentas; reducción de costos; amplía los mercados existentes ${ }^{2}$; incrementa las áreas de actividad empresarial al crear otras con productos inmateriales basados en el conocimiento; y en consecuencia, permite a los consumidores disponer de más posibilidades de elección al extender la oferta (Pardo, 2003) generando a su vez relaciones de consumo transfronterizas.

En la actualidad, los contratos internacionales quedan como instrumentos de intercambio, exclusivos entre comerciantes, para dar paso a los contratos de consumo internacional entre empresarios y particulares que adquieren bienes o servicios para uso doméstico, en un entorno en el que los costos de colaboración empresarial se disminuyen, generando participación de diversas modalidades de intermediación y

2 Así lo reconoce la Directiva (31/2000/31) sobre comercio electrónico, la cual consagra en su motivo segundo que: "el desarrollo del comercio electrónico en la sociedad de la información ofrece importantes oportunidades para el empleo en la comunidad, especialmente para las pequeñas y medianas empresas, que facilitará el crecimiento de las empresas europeas, así como las inversiones en innovación, y también puede incrementar la competitividad de la industria europea, siempre y cuando Internet sea accesible para todos". 
colaboración (los bancos facilitan los contratos con sus sistemas de pago con las tarjetas de crédito y débito, las compañías de transporte contratadas para hacer las entregas de los bienes adquiridos, las compañías aseguradoras, etc.) en los que se evidencian, grandes desafíos en torno a la competencia jurisdiccional, la normatividad aplicable, los sistemas de seguridad y la protección efectiva de los derechos de los intervinientes, entre muchos otros aspectos.

La creciente mutación de los mercados físicos a virtuales y el crecimiento de los ya virtuales, son una realidad y que todo parece indicar que estamos en las fases incipientes de esta red y de su mercado, que en sus orígenes, se caracterizaron por la no regulación -legal, comercial y arancelaria- lo que propició riqueza, efectos no esperados en la sociedad, las personas y sus bienes (irrupción de los delitos informáticos, el manejo indebido de los datos personales, nuevas adicciones a la red y sus muy populares redes sociales entre otros), y que han sido los principales motores de impulsión en la promulgación de marcos legales con diferentes alcances y dentro de los más distintos escenarios ${ }^{3}$, apuntando al fortalecimiento del comercio electrónico, de sus sistemas de seguridad, de las efectivas medidas de control, transparencia y protección de los consumidores frente a prácticas fraudulentas, de la vigilancia por la evasión fiscal, y la protección de la propiedad industrial e intelectual, por resaltar algunos.

3 El recién aprobado tratado de libre comercio (TLC) con Colombia por el Congreso norteamericano tiene todo un capítulo dedicado al comercio electrónico, véase http://www.sice.oas.org/TPD/AND_USA/COL_ USA/Draft_text_050806_s/15\%20COMERCIO\%20 ELECTRON̄ICŌ.pdf

4 Las condiciones generales pueden definirse, siguiendo a De Castro (1965), como "los conjuntos de reglas que un particular (empresario, grupo o rama de industriales o comerciantes) ha establecido para fijar el contenido (derechos y obligaciones) de los contratos que sobre un determinado tipo de prestaciones se propone realizar" (p.45).

5 Pero por otra parte se apartan estos contratos de los de adhesión convencionales, en que existe una desmaterialización del soporte del documento, expresado en soportes y caracteres digitales que se
En el comercio electrónico se puede celebrar contratos de negociación individual como contratos adhesión, siendo estos últimos los que más han ocupado los nacientes procesos legislativos, no solo por ser los más comunes sino por evidenciarse en ellos asimetrías informativas, económicas y jurídicas. Estos contratos electrónicos se caracterizan por la impersonalidad (que es elevada a niveles desconocidos) y por reunir todas las técnicas de la contratación en masa: contrato de adhesión con condiciones generales predispuestas ${ }^{4}$, con un marketing agresivo, cautividad del cliente e internacionalidad de muchas relaciones, más la distancia física entre proveedor y consumidor ${ }^{5}$ (Weingarten, 2007).

Por lo anterior, ha sido una constante en los marcos normativos europeos y latinoamericanos que regulan la materia, el incorporar sendos capítulos -en los títulos de la formación del contrato- sobre derechos de información ${ }^{6}$, obligaciones de informar, cláusulas de condiciones predispuestas, efectos de la publicidad ${ }^{7} y$ normas concretas sobre la responsabilidad civil con ocasión al incumplimiento de dichas cargas informativas vinculadas, incluso, a la calificación de los productos como defectuosos. Todo lo dicho, como verdaderas medidas de contingencia respecto a la siempre insuficiente regulación, los escasos conocimientos técnicos sobre la forma y el objeto contractual por parte del consumidor y sobre todo, la "oscuridad" en la que se realizan este tipo de transacciones, en donde se aumenta

pueden almacenar y conservar de forma estable, íntegra y fiel; la necesidad de determinados conocimientos; la posible posición hegemónica de la parte que posea mejor conocimiento y calidad técnica; el flujo de datos de carácter personal y patrimonial en algunos casos con efectos transfronterizos (Barrioso, 1998).

6 No en vano se afirma que en el caso de la obligación de información se han conocido los desarrollos más espectaculares (Malauri, 1987).

7 Al considerarse en la actualidad como un valor contractual. En el comercio electrónico se desdibujan las fronteras entre la publicidad, la oferta y el contrato propiamente dicho: los anuncios de un sitio web pueden servir de base para la determinación del alcance de la contratación con el proveedor (De Nayer y Laffineur, 2000). 
el riesgo y la inseguridad para los consumidores y redundan en la ralentización del desarrollo del sector (Ancos, 2001).

Con lo anterior, pondremos a prueba nuestra reciente ley (1480/2011) por medio de la cual se promulga un Nuevo Estatuto de Consumo $(\mathrm{NEC})^{8}$, con miras a identificar, si en sus capítulos se reglamentó las obligaciones pre y poscontractual de información, atendiendo las tendencias internacionales que sobre la materia se han ido desarrollando, en especial, en el sistema jurídico europeo.

\section{NOCIONES INTRODUCTORIAS SOBRE EL COMERCIO ELECTRÓNICO}

Al hacer referencia al comercio electrónico 9 tenemos que partir de una definición amplia, entendido como cualquier forma de transacción o intercambio de información comercial basada

8 El 10 de agosto de 2011 se aprobó en sesión plenaria del Senado de la República el proyecto de ley 252/2011, el cual fue tramitado en la Cámara de Representantes. La sanción presidencial se dio el 12 de octubre de 2011, y desde ese entonces es la ley 1480/2011, la cual entró en vigencia a los seis meses al tenor del art. 84 . En adelante la denominaremos como el Nuevo Estatuto de Consumo (NEC). Por último, es importante recordar que en la ley $527 / 1999$, por medio de la cual se define y reglamenta el acceso y uso de los mensajes de datos, del comercio electrónico y de las firmas digitales, y se establecen las entidades de certificación y se dictan otras disposiciones, encontramos algunas normas generales que regulan el comercio electrónico, no obstante, la opinión desde este trabajo, es que en el ámbito de los derechos de los consumidores, son inexistentes los aportes.

9 Se afirma que antes que la Internet apareciera, ya existía un comercio electrónico en redes, donde las empresas en entornos cerrados de comunicación, hacían diversas transacciones, como por ejemplo, las desarrolladas en el ámbito bancario del mercado de valores (Fernández, s. f.).

10 Son diversos los servicios de la sociedad de información, siendo tan solo uno más de ellos el contrato electrónico. Al respecto la directiva sobre comercio electrónico, plantea en su motivación 18 que: "Los servicios de la sociedad de la información cubren una amplia variedad de actividades económicas que se desarrollan en línea; dichas actividades en particular consisten en la venta de mercancías en línea. Las actividades como la entrega de mercancías en sí misma o la prestación de servicios fuera de la línea no están cubiertas. Los servicios de la sociedad de la información no se limitan únicamente a servicios que dan lugar a la contratación en línea, sino en la transmisión de datos sobre redes de comunicación como Internet, con lo cual se incluye la compraventa, considerada en sí, y el conjunto de actividades previas a las mismas como la publicidad, la búsqueda de información, las ofertas, la contratación previa, etcétera ${ }^{10}$.

A pesar de que el ordenamiento colombiano optó por una descripción más genérica, se observa que en general, se ajusta a los términos globales, así la ley 527/199911, definió en su artículo 1.b al comercio electrónico como aquel que abarca las cuestiones suscitadas por toda relación de índole comercial ${ }^{12}$, sea o no contractual, estructurada a partir de la utilización de uno o más mensajes de datos o de cualquier otro medio similar. Definición que se mantuvo a grandes rasgos en la NEC artículo $49^{13}$, incluyendo que dichas transacciones pueden consistir en actos, negocios u operaciones mercantiles.

también, en la medida en que representan una actividad económica, son extensivos a servicios no remunerados por sus destinatarios, como aquellos que consisten en ofrecer información en línea o comunicaciones comerciales, o los que ofrecen instrumentos de búsqueda, acceso y recopilación de datos. Los servicios de la sociedad de la información cubren también servicios consistentes en transmitir información a través de una red de comunicación, o albergar información facilitada por el destinatario del servicio.

11 "Por medio de la cual se define y reglamenta el acceso y uso de los mensajes de datos, del comercio electrónico y de las firmas digitales, y se establecen las entidades de certificación y se dictan otras disposiciones".

12 Afirma la ley en el art. 1.b: "Las relaciones de índole comercial comprenden, sin limitarse a ellas, las siguientes operaciones: toda operación comercial de suministro o intercambio de bienes o servicios; todo acuerdo de distribución; toda operación de representación o mandato comercial; todo tipo de operaciones financieras, bursátiles y de seguros; de construcción de obras; de consultoría; de ingeniería; de concesión de licencias; todo acuerdo de concesión o explotación de un servicio público; de empresa conjunta y otras formas de cooperación industrial o comercial; de transporte de mercancías o de pasajeros por vía aérea, marítima y férrea, o por carretera".

13 Sin perjuicio de lo establecido en el artículo $1^{\circ}$, inciso b) de la ley 527/1999, "se entenderá por comercio electrónico la realización de actos, negocios u operaciones mercantiles concertados a través del intercambio de mensajes de datos telemáticamente cursados entre proveedores y los consumidores para la comercialización de productos y servicios". 
En la doctrina es de pacífica aceptación un concepto amplio con componentes más técnicos. Partiendo del simple hecho, de que el comercio electrónico conlleva a actividades de diversa índole, así un prestador del servicio puede estar en Internet simplemente facilitando información sobre los bienes y servicios que le ofrece a los usuarios; facilitar cierto diálogo en línea con el usuario o consumidor que se interese en alguno de los bienes o servicios que presta pero sin llegar a proporcionar la posibilidad de realizar contratación electrónica, así como ofrecer a los usuarios y consumidores la contratación de productos o la recepción de servicios por vía electrónica, en este último caso, cumpliendo con las exigencias propias de la contratación que realice y las exigencias específicas del medio por el que las realiza (Arias, 2006).

Para la Comisión Europea en la comunicación $97^{14}$, texto preparatorio de la directiva $31 / 2000$ CE (directiva del comercio electrónico), el comercio electrónico consiste en realizar, electrónicamente, transacciones comerciales. Se basa en el tratamiento y la transmisión electrónica de datos, incluidos textos, imágenes y vídeo. El comercio electrónico comprende actividades muy diversas, como comercio electrónico de bienes y servicios, suministro en línea de contenidos digitales, transferencia electrónica de fondos, compraventa electrónica de acciones, conocimientos de embarque electrónicos, subastas, diseños y proyectos conjuntos, prestación de servicios en línea (on one sourcing), contratación pública, comercialización directa al consumidor y servicios posventa. Por tanto, abarca a la vez productos (p. ej., bienes de consumo, equipo médico especializado) y servicios (p. ej. servicios de información, financieros y jurídicos), actividades tradicionales (p. ej. asistencia sanitaria, educación) y nuevas actividades (p. ej. centros

14 Denominada iniciativa europea sobre comercio electrónico.

15 Según el profesor Huet (1997, p. 27), "en el comercio electrónico lo que los interlocutores ganan en materia de acceso a productos y servicios disponibles, lo pierden dramáticamente en diálogo y en la negociación. Lo que comerciales virtuales) (Comisión de las Comunidades Europeas, 1997). Incluso, frente a la pluralidad de redes informáticas, la multiplicidad de transacciones e intercambios y la diversidad de actores, son entendibles aquellas definiciones que consideran al comercio electrónico "como toda forma de comercio en la cual se utilizan las redes de los ordenadores como medio de comunicación entre los diferentes agentes implicados" (Vila, 2001, p. 51).

De acuerdo con nuestro objetivo, nos detendremos en el más común de los actos comerciales -el contrato- que se realizan en la red, y para proceder a un análisis sistemático de la contratación electrónica y de los diversos controles legales, en especial los informativos, que existen hoy, durante todo el iter contractus, es necesario hacer una revisión a las directivas comunitarias que regulan la materia, lo que nos permitirá tener una referencia para evaluar las recientes instituciones insertas en el NEC.

\section{SOBRE LA NATURALEZA Y LAS COMPLEJIDADES DE LA CONTRATACIÓN ELECTRÓNICA}

A pesar de las diversas discusiones sobre el establecimiento y la naturaleza de los contratos celebrados por medios electrónicos, para nosotros no corresponden a un tipo contractual diferente a los que ya existen, sino a una simple modalidad de contratación como lo menciona Domínguez $(2007)^{15}$. Ahora lo que sucede es que la contratación electrónica reviste diversas complejidades y particularidades que se acentuarán o no, dependiendo de los intervinientes, de tal forma si en un extremo encontramos un consumidor y en el otro un comerciante, la legislación plantea unos controles y requisitos concretos sobre los que nos pronunciaremos a continuación. Al

\footnotetext{
hace que sea necesario ver al contrato ya no como un acuerdo de voluntades que se expresan y convergen, sino como el resultado de una respuesta positiva a una proposición estandarizada y por tanto lejos de una verdadera aceptación [...]".
} 
no tener una definición legal en Colombia del contrato electrónico ${ }^{16}$, acudiremos a hacer una revisión en el ámbito español y comunitario sobre la materia.

En el panorama español por ejemplo siguiendo el punto h del anexo de la ley 34/2002, de 11 de julio (Ley de Servicios de la Sociedad de la Información y del Comercio Electrónico, LSSICE) "el celebrado por vía electrónica es todo contrato en el que la oferta y la aceptación se transmiten por medio de equipos electrónicos de tratamiento y almacenamiento de datos, conectados a una red de telecomunicaciones".

Lo anterior permite inferir que por lo menos, desde el análisis legal, según las diversas definiciones, no se corresponde a un contrato diferente al reglado incluso en los códigos decimonónicos, sino que estamos ante un negocio jurídico delimitado en función de la forma utilizada (Domínguez, 2007).

Un poco más ilustrativa y precisa es la definición de Ontiveros y Mora (2003) al afirmar que es aquella modalidad contractual que se caracteriza porque su formación y perfección se produce de forma electrónica o en línea, es decir, mediante la transmisión de datos a través de redes telemáticas. De acuerdo con esto, es común identificar dos características concretas de este tipo de negocios jurídicos, de los convencionales (o tradicionales o físicos), por una parte, es un contrato entre personas distantes (contratos a distancia) ${ }^{17}$ y por otra, se celebra por medio de la transmisión de datos por redes telemáticas ${ }^{18}$. No siendo el objeto de este escrito estudiar los elementos particulares de este tipo de contratos, nos limitaremos a recordar que los contratos electrónicos se desarrollan en tres fases: (i) un mensaje transmitido por medio telemático (en las páginas web), en el que se ofrecen productos o

16 ElNEC en su art. 5 hizo referencia pero no dio definición alguna, asimilando simplemente este tipo de contratos a los de la categoría de ventas a distancia. Consagró: ventas a distancia: "Son las realizadas sin que el consumidor tenga contacto directo con el producto que servicios; (ii) con soporte en él, el consumidor o usuario efectúa su pedido (manifiesta su consentimiento) y (iii) luego recibirá el bien o servicio suministrado por el empresario.

Entre los atributos relevantes de los contratos celebrados por medios electrónicos se destacan tres criterios de clasificación: el medio por el que se perfeccionan, por la forma de su cumplimiento o ejecución, y por los sujetos que intervienen (Arias, 2006), como se verá a continuación; con ocasión a esta última y especial división, se ha desarrollado normativamente el derecho de las nuevas tecnologías y sobre todo, en el ámbito protector en favor de los consumidores en cuanto al modo de celebración de los contratos (entre personas no presentes, a distancia, por medio de equipos electrónicos), y a las características (desconocimiento técnico, material) de los intervinientes. De ahí que se tengan diversas normas de control sobre las condiciones generales (su accesibilidad, disponibilidad y comprensibilidad) y diversos mecanismos de protección (revocación, integración de la publicidad al contrato, entre otros) entre los que destacaremos las obligaciones de información pre y poscontractual.

Retomando nuestros tres criterios, comenzaremos por recordar que según el medio por el que se perfeccionan los contratos electrónicos, se pueden diferenciar aquellos en los que la oferta y la aceptación se hacen a través del correo electrónico, con aquellos que a la aceptación se llega previa aceptación (haciendo clic y complementando) de los pasos o fases que el oferente ha preestablecido y en donde se determinan la clasificación del objeto, forma de pago, y datos personales y de envío.

Desde su ejecución o cumplimiento, es común la clasificación de comercio electrónico directo e indirecto. En el primero la oferta, la aceptación

adquiere, que se dan por medios, tales como correo, teléfono, catálogo o vía comercio electrónico".

17 Regulados por la directiva (7/1997).

18 Sobre la materia se puede consultar un texto muy completo, el de Arias (2006). 
y el objeto del contrato y su cumplimiento, se perfeccionan y se ejecutan por los canales digitales, son comunes de estos mercados los bienes (productos) y servicios intangibles, por ejemplo, los e-book, la consulta de bases de datos, y en general, servicios de información ${ }^{19}$. Mientras que en comercio electrónico indirecto, el contrato nace por esta vía (la oferta y la aceptación se hacen por este medio) pero su cumplimiento (ejecución) se realiza físicamente, de la forma tradicional ${ }^{20}$.

Desde la perspectiva del cumplimiento de las obligaciones, el comercio directo suele tener dos modalidades, la más común es la que permite una descarga del bien (download) o aquella en la que el bien o servicio se recibe vía correo electrónico. Esta clasificación normalmente tiene una importancia trascendental sobre todo en lo que corresponde al ejercicio del derecho de retractación (que como es sabido, tiene por objeto un fin de garantía en cuanto a la idoneidad del consentimiento otorgado en la relación de consumo), ya que difícilmente puede ejercerse este derecho sobre bienes ya entregados (al ser información o derechos de fácil reproducción, o en muchos casos no siendo posible al otorgarse por ejemplo un acceso limitado a una web concreta).

Según los intervinientes, los contratos pueden ser con profesionales entre sí, conocidos en el lenguaje anglosajón como business to business (B2B) los que a su vez se rigen por la autonomía de la voluntad como regla principal, los contratos entre profesionales y consumidores business to consumers (B2C) en los cuales la autonomía de la voluntad es menor al aplicar las leyes de protección al consumidor lo que le da matices de derechos sociales, los contratos con las administraciones públicas business to government o business to administration (B2G o B2A), y entre sí (en las que los marcos normativos en cuanto a su naturaleza oscilan entre el derecho público y privado), los contratos entre consumidores

19 Muy populares las compras en línea de software o la celebración de contratos de music-on-demand, videoon-demand o books-on-demand.

20 Para mayor información, véase Mata y Martín (2001).

21 Artículo 22, "aplicación de la ley comercial a los actos consumers to consumers $(\mathrm{C} 2 \mathrm{C})$ regidos por la autonomía privada, e incluso las combinaciones entre todos ellos.

\section{EL MARCO NORMATIVO}

En el panorama colombiano, así como en el de la mayoría de los países (incluso los europeos), no existe una ley concreta que regule el contrato electrónico. Por tanto, para identificar su sistema legal aplicable es necesario hacer un ejercicio sistemático de fuentes y para ello debemos partir de la idea central de que los contratos electrónicos son primero contratos y luego electrónicos (Arias, 2006), de tal forma que se aplican las normas generales que regulan los contratos, y las leyes especiales existentes sobre la materia, las cuales vía principio de especialidad serán siempre de prevalencia. No siendo un asunto sencillo la determinación normativa, dentro de la cual hay que tener en cuenta el tipo de contrato, el objeto pretendido y los intervinientes.

En el escenario nacional la aplicación del sistema de fuentes es doblemente compleja. Porque las normas son escasas (salvo la ley 527/1999) y frecuentemente habrá que acudir al Código Civil que reguló defectuosamente el contrato entre personas distantes, y porque no se tuvo clara la prevalencia de la norma especial (en este caso la de consumo) frente la eventualidad de conflictos normativos (como funcionaba de tiempo atrás en Europa y Latinoamérica) entre las normas de comerciales y de consumo. En Colombia solo con la entrada en vigencia del NEC, y en su nombre el art. 4, se pone fin a años de confusión en torno a la aplicación e interpretación del art. $22^{21}$ del Código del Comercio que siempre fue excesiva y desproporcionada (estudiándose desde una vocación exclusiva del comerciante $e^{22}$ ), y que confinó a las normas de consumo a una inaplicación constante o indebida. La norma dispone:

mercantiles". Si el acto fuere mercantil para una de las partes se regirá por las disposiciones de la ley comercial.

22 Al revisar los manuales de derecho comercial no se encuentra capítulo alguno dedicado a los consumidores. Así, López (2008) y Narváez (2009), por tan solo resaltar algunos de los textos más representativos. 
Art. 4 (NEC). En lo no regulado por esta ley, en tanto no contravengan los principios de la misma, de ser asuntos de carácter sustancial se le aplicarán las reglas contenidas en el Código de Comercio y en lo no previsto en este, las del Código Civil. En materia procesal, en lo no previsto en esta ley para las actuaciones administrativas se le aplicarán las reglas contenidas en el Código Contencioso Administrativo y para las actuaciones jurisdiccionales se le aplicarán las reglas contenidas en el Código de Procedimiento Civil, en particular las del proceso verbal sumario.

Clarificada la situación aplicaremos siempre en el marco de una relación de consumo el NEC, y los vacíos normativos serán surtidos por el Código de Comercio y Civil. En este punto lo ideal sería que el legislador hubiera invertido el orden de aplicación de los códigos, toda vez que al preferir en órdenes el Código Civil por el del Comercio se estaría más en armonía y dentro del ambiente proteccionista que caracteriza la norma de consumo, ya que es por todos conocido el plano de igualdad y de equidad legal que defiende la norma decimonónica, caso contrario de la norma de clase que es el Código del Comercio. Resuelta así, la aplicación de la ley en los asuntos de consumidores y en los contratos electrónicos en los que ellos participan (tema de estudio), nos faltaría analizar el sistema de fuentes por aplicar cuando los contratos electrónicos son celebrados

23 Que buscaba el aumento del conjunto de garantías jurídicas a favor del consumidor que decide adquirir productos y servicios a través de mecanismos comerciales basados en la venta a distancia. Tiene además la misión de la transposición al ordenamiento español de las directivas 97/7/CE sobre contratos a distancia y la adaptación de la ley a otras directivas comunitarias: la 44/1999/CE sobre determinados aspectos de la venta y garantía de los bienes de consumo y la 35/2000/CE por la que se establecen medidas de lucha contra la morosidad en las operaciones comerciales. Para ampliar la información, véase García (2004).

24 Así lo expresa el art. 23 de la LSSICE: "Validez y eficacia de los contratos celebrados por vía electrónica. 1. Los contratos celebrados por vía electrónica producirán todos los efectos previstos por el ordenamiento jurídico, cuando concurran el consentimiento y los demás requisitos necesarios para su validez. Los contratos electrónicos se regirán por lo dispuesto en este título, por los códigos por sujetos diversos. Así, cuando estamos frente a actos, contratos u operaciones mercantiles (electrónicas) entre B2B, se dará aplicación al sistema de fuentes de lo mercantil, y en aquellos eventos en los que intervienen sujetos no comerciantes aplicaremos las normas del Código Civil, como fuente primaria.

Si revisamos el ámbito español tendremos que hacer un ejercicio de integración sistemática entre diversas normas, destacando entre ellas: la ley 26/1984 de 19 de julio, Ley General para la Defensa de los Usuarios y Consumidores (LGDUC); la ley 7/1998 de 13 de abril, de Condiciones Generales de la Contratación; el real decreto 1906/1999 de 17 de diciembre, que regula la contratación telefónica o electrónica con condiciones generales; la ley 26/1991 de 21 de noviembre, sobre contratos celebrados fuera de establecimientos mercantiles; la ley 15/1999 de 13 de diciembre, Ley Orgánica de Protección de Datos de Carácter Personal (LOPD); la ley 7/1996 de 15 de enero, Ley de Ordenación del Comercio Minorista (LOCM), con su ley modificadora de los contratos y servicios a distancia; la ley 47/2002, de 19 de diciembre ${ }^{23}$; la ley 34/2002 de 11 de julio, LSSICE, trata en los artículos 23-29 los asuntos del contrato electrónico; la ley 34/1988 de 11 de noviembre, Ley General de Publicidad; las normas del Código de Comercio y las del Código Civil ${ }^{24}$.

civil y de comercio y por las restantes normas civiles o mercantiles sobre contratos, en especial, las normas de protección de los consumidores y usuarios y de ordenación de la actividad comercial. 2. Para que sea válida la celebración de contratos por vía electrónica no será necesario el previo acuerdo de las partes sobre la utilización de medios electrónicos. 3. Siempre que la ley exija que el contrato o cualquier información relacionada con el mismo conste por escrito, este requisito se entenderá satisfecho si el contrato o la información se contiene en un soporte electrónico. 4. No será de aplicación lo dispuesto en el presente título a los contratos relativos al derecho de familia y sucesiones. Los contratos, negocios o actos jurídicos en los que la ley determine para su validez o para la producción de determinados efectos la forma documental pública, o que requieran por ley la intervención de órganos jurisdiccionales, notarios, registradores de la propiedad y mercantiles o autoridades públicas, se regirán por su legislación específica”. 
En el ámbito comunitario rige la directiva 31/2000/ CE del Parlamento Europeo y del Consejo de 8 de junio de $2000^{25}$, relativa a determinados aspectos jurídicos de los servicios de la sociedad de la información, en particular, el comercio electrónico en el mercado interior (directiva sobre el comercio electrónico), cuyo objetivo es crear un marco jurídico que garantice la libre circulación de los servicios de la sociedad de la información entre Estados miembros, dedicando, para ello. a la contratación por vía electrónica, los artículos 9-11, donde se destaca el deber que tienen los Estados miembros de velar por la celebración de contratos de este tipo, el cumplimiento de los deberes de información previa ${ }^{26} \mathrm{y}$ posterior.

\section{La obligación de información como el elemento diferenciador en los contratos entre profesionales y consumidores}

En el ámbito español, y en general, en los demás países que conforman la Unión Europea, la aplicación de las normas sobre la materia no es un ejercicio sencillo, por su multiplicidad y las situaciones tan particulares en las que las leyes

25 La complejidad normativa trasciende el ámbito de los Estados miembros, y alcanza las esferas comunitarias. Así la directiva comunitaria 31/2000 establece que dicha norma coexistirá con los diversos instrumentos comunitarios entre otras, la directiva 13/1993/CEE del Consejo, de 5 de abril de 1993, sobre las cláusulas abusivas en los contratos celebrados con consumidores y la directiva 7/1997/CE del Parlamento Europeo y del Consejo, de 20 de mayo de 1997, relativa a la protección de los consumidores en materia de contratos a distancia constituyen un instrumento esencial para la protección del consumidor en materia contractual. Dichas directivas se seguirán aplicando en su integridad, a los servicios de la sociedad de información, también forman parte del acervo comunitario plenamente aplicable a los servicios de la sociedad de la información y en particular, la directiva 450/1984/CEE del Consejo, de 10 de septiembre de 1984, sobre publicidad engañosa y publicidad comparativa, la directiva 102/1987/CEE del Consejo, de 22 de diciembre de 1987, relativa a la aproximación de las disposiciones legales, reglamentarias y administrativas de los Estados miembros en materia de crédito al consumo. La directiva 22/1993/CEE del Consejo, de 10 de mayo de 1993, relativa a los servicios de inversión en el ámbito de los valores negociables, la directiva 314/1990/CEE del Consejo, de 13 de junio de 1990 , relativa a los viajes combinados, las vacaciones combinadas y los circuitos combinados, la directiva 6/1998/CE del Parlamento Europeo y del Consejo, de 16 de febrero de 1998, relativa a la protección de los actúan en diversos planos, de tal suerte que hay reglas que se aplican en todo tipo de relaciones comerciales con comerciantes (B2B), y hay otras en cuyo ámbito especial de protección, solo puede hacerse en presencia de una relación profesional y consumidor (B2C).

Así por ejemplo en España, según la ley 34/2002 de 11 de julio, LSSICE, serán transversales las normas sobre validez y eficacia de los contratos (art. 23), la prueba de los contratos (art. 24), la intervención de terceros para archivar las declaraciones de voluntad (art. 25) y el lugar de celebración del contrato (art. 29), mientras que encontraremos diversos preceptos que están destinados a la relación entre profesionales y consumidores (B2C), entre las más significativas, las obligaciones previas al inicio del procedimiento de contratación (art. 27), y la información posterior a la celebración del contrato (art. 28). Todo con la particularidad de que si la relación contractual es entre profesionales y consumidores, los artículos 27 y 28 serán imperativos, mientras que si el vínculo es entre profesionales serán dispositivos (Domínguez, 2007).

consumidores en materia de indicación de los precios de los productos ofrecidos a los consumidores, la directiva 59/1992/CEE del Consejo, de 29 de junio de 1992, atinente a la seguridad general de los productos, la directiva 47/1994/CE del Parlamento Europeo y del Consejo, de 26 de octubre de 1994, sobre el derecho de utilización de inmuebles en régimen de tiempo compartido, la directiva 27/1998/CE del Parlamento Europeo y del Consejo, de 19 de mayo de 1998, relativa a las acciones de cesación en materia de protección de los intereses de los consumidores, la directiva 374/1985/CEE del Consejo, de 25 de julio de 1985, relativa a la aproximación de las disposiciones legales, reglamentarias y administrativas de los Estados miembros en materia de responsabilidad por los daños causados por productos defectuosos, la directiva 44/1999/CE del Parlamento Europeo y del Consejo, de abril de 1999, sobre determinados aspectos de la venta y las garantías de los bienes de consumo, la futura directiva del Parlamento Europeo y del Consejo relativa a la comercialización a distancia de servicios financieros destinados a los consumidores y la directiva 28/1992/CEE del Consejo, de 31 de marzo de 1992, relativa a la publicidad de los medicamentos para uso humano.

26 Menciona la directiva en el art. 10, que aparte de los deberes de información previos a cualquier pedido, deberán también observarse los demás requisitos en materia de información contemplados en el derecho comunitario. 
La diferenciación radica en lo relacionado con la información de contenido precontractual considerada como esencial para la formación del consentimiento de su destinatario, el consumidor. De tal forma que con ocasión al nivel de experticia, los contenidos de información por transmitir entre expertos no será el reglado, sino el que fije las prácticas, los usos, las costumbre y en general, la buena fe objetiva ${ }^{27}$ y las normas mercantiles que rijan la materia ${ }^{28}$.

En el ámbito nacional, no se presenta dicha complejidad al no existir leyes transversales sobre el asunto, dando aplicación al sistema de fuentes, no obstante, como se verá a continuación, tienen la misma identidad normativa las obligaciones de información que recaen sobre los expertos en la contratación electrónica. A pesar de que no son del todo novedosas en el plano comunitario, sí vendrían a consolidar, por las expresas, disposiciones de la directiva 31/2000, según la cual cuando el profesional (el prestador de servicios de la sociedad de la información), realiza actos de contratación electrónica, tiene dos obligaciones específicas, una previa de información y otra posterior, y da continuidad a la política esbozada en la directiva sobre contratación a distancia ${ }^{29}$. $\mathrm{Y}$ a su vez, diversas obligaciones generales de carga informativa que estudiaremos en seguida, no sin antes hacer un recuento de las diversas justificaciones jurídicas y económicas que las respaldan y que sirvieron de sustento también en el NEC.

27 Sobre el contenido de la información precontractual entre expertos, ya tuvimos la oportunidad de manifestarnos en un estudio histórico y dogmático. Véase Monsalve (2008).

28 En el caso colombiano el fundamento normativo sería el artículo 863 del Código del Comercio, sobre el que ya nos hemos pronunciado (Monsalve, 2008).

29 Pese a existir desde 1997, según la directiva 7/1997, una regulación concreta para el caso de los contratos celebrados a distancia en el ámbito europeo, los órganos legislativos optaron por el establecimiento de unas reglas especiales aplicables de modo preferente al interior de los contratos oficiados por vía electrónica.

30 En la literatura jurídica francesa existe un texto muy relevante sobre la materia donde se aborda la naturaleza, el concepto y en general, todo el régimen del equilibrio contractual. Véase Fin-Langer (2002).

31 Existe un clásico artículo escrito en los años setenta con el que se explica el problema de las pequeñas compañías

\section{LAS OBLIGACIONES PRECONTRACTUALES DE INFORMACIÓN}

La protección al consumidor usualmente orienta su justificación a partir de la caracterización de la relación de consumo por el desequilibrio ${ }^{30}$ entre sus partes. Así, se asume que el consumidor se encuentra en una condición natural de inferioridad o debilidad con respecto al proveedor profesional de bienes o servicios y entre otras razones, otorgada por el poder de los grandes empresarios (que en el caso colombiano se acrecienta por la presencia de diversos monopolios legales o de hecho), por el oportunismo de los comerciantes $^{31}$, por los altos $\operatorname{costos}^{32}$ de adquirir información y por la productividad ${ }^{33}$ que genera para el proveedor.

Pero en general, la obligación de información halla su razón de ser (por criterios mayoritarios) en un desequilibrio de conocimientos entre los contratantes. El cual puede deberse a dos causas (Boyer, 1978), en primer lugar, a la propia técnica de formación de los contratos y en segundo lugar, a las circunstancias conforme a las calidades de los contratantes o por mandato de la ley.

La técnica de formación del contrato típico, en los llamados contratos de adhesión donde el consumidor acepta un clausulado general preestablecido, existiendo ausencia de negociaciones ${ }^{34}$

en mercados atomizados donde sus comportamientos oportunistas afectan el mercado vía manipulación de las variables calidad-precio. Véase Akerlof (1970).

32 En aquellos casos en que, si bien la adquisición de información requiere más inversión, sus costos son asimétricos (mayores para una parte que para la otra), lo más coherente desde el punto de vista económico es atribuir el deber de información a la parte que está en condiciones de adquirirla a un costo más bajo.

33 Consiste, según Harsanyi (1967), en que: "si el valor que cuesta conseguir la información es más bajo que las ventajas que se obtendrán con la comercialización de la misma, o de un bien o servicio específico deberá ser cubierto por quien se beneficia o se lucra de ella" (p. 23).

34 Es en esta etapa donde a las partes se les permite evaluar de antemano las posibilidades técnicas y las oportunidades económicas o de conveniencia del contrato o acuerdo que se pretende celebrar, en relación con los propósitos que cada sujeto aspira alcanzar (Monsalve, 2011). 
El desequilibrio de conocimientos entre los contratantes puede venir determinado en función de las circunstancias. Es decir, que uno de los contratantes estará obligado a informar al otro siempre que se encuentre al corriente de un elemento que la otra parte tiene interés en conocer, pero que ignora legítimamente. El principio es aplicable a todos los negocios sin importar la calidad o condición de los mismos, según el mandato de la buena fe. Se hace mucho más presente en los vínculos de consumo, donde es el productor o empresario, el que está llamado a suministrar la información por directa indicación legal. O en los casos de formación contractual, entre una parte que actúa como experto y otra que se encuentra en amplio desequilibrio.

En el contrato electrónico desde la técnica de formación, la evidencia de diversos desequilibrios basados principalmente en la no presencia física de las partes, hace que los clientes potenciales tengan a su disposición elementos que son fuente clave de confianza y que si están presentes en el comercio tradicional, se hallan asociados a la contratación entre presentes en el marco de un establecimiento mercantil conocido en el que están disponibles los bienes objeto del contrato, lo que facilita el acceso a la información, a probarlos, constatarlos, y así, proclives a la manifestación del consentimiento, con mayores probabilidades de estar libre de vicios ${ }^{35}$.

Ahora, si se analiza desde los contratos electrónicos entre $\mathrm{B} 2 \mathrm{C}$, identificamos que se halla inserto en las dos consideraciones enunciadas, lo cual justifica la necesidad de implementar instrumentos jurídicos para restablecer el equilibrio contractual, con fundamento, básicamente, en nociones de

35 En el ámbito portugués existe un excelente escrito que de forma concreta trata la materia (Dias, 2004). En el ámbito español y ya no desde la Internet, sino desde la celebración de los contratos a distancia, profundo el análisis sobre los vicios que desarrolla García (1997).36

36 Para mayor información, véase Monsalve y Rodado (2010).

37 En la motivación 29 la directiva sobre comercio electrónico expresamente consagra: (29) "Las comunicaciones comerciales son esenciales para financiar los servicios justicia correctiva y en una alta carga de teoría económica cuyo análisis ya hemos hecho ${ }^{36}$.

A lo expuesto deberá adicionarse que es necesaria la protección por motivos de transparencia en las relaciones de consumo, y por la buena fe objetiva que se debe en la relación humana. Así lo desarrolla en una buena medida la directiva 31/2000 (sobre comercio electrónico), cuando afirma que en aras del interés de los consumidores y en beneficio de la lealtad de las transacciones, las comunicaciones comerciales deben respetar algunas obligaciones en cuanto a su transparencia ${ }^{37}$.

Por otra parte, recuérdese que el alcance global de las aplicaciones de Internet determina que las eventuales ventajas para los consumidores asociadas al acceso a ofertas y contenidos procedentes de cualquier lugar del mundo vayan unidas a particulares riesgos, en la medida en que los niveles y reglas de protección de los consumidores varían, sustancialmente, según los países. Ello implica que la eventual localización del proveedor en el extranjero sea normalmente fuente de inseguridad jurídica cuando el consumidor pretende interponer alguna reclamación, en lo que concierne a los órganos competentes para conocer de la misma, y en la normativa que será de aplicación, e incluso a la eventual efectividad de las medidas que en su caso puedan adoptar las autoridades o tribunales del Estado del domicilio del consumidor. Así, la posición de consumidor reclama una especial tutela en las transacciones internacionales, pues factores como el carácter ocasional de la actividad transfronteriza de los consumidores y sus limitados recursos, condicionan la presencia de dificultades específicas

de la sociedad de la información y el desarrollo de una amplia variedad de servicios nuevos y gratuitos. En interés de los consumidores y en beneficio de la lealtad de las transacciones, las comunicaciones comerciales -incluidas las rebajas, ofertas y concursos o juegos promocionales- deben respetar algunas obligaciones en cuanto a su transparencia; dichas obligaciones se entenderán sin perjuicio de lo dispuesto en la directiva 97/7/CE. Lo dispuesto en la presente directiva deberá entenderse sin perjuicio de las directivas existentes sobre comunicaciones comerciales y, especialmente, la directiva 98/43/CE. 
en relación, por ejemplo, con el uso de idiomas extranjeros o la necesidad de conocer un ordenamiento extranjero (De Miguel, 2008).

A pesar de tenerse ampliamente documentado lo anterior, son todavía asignaturas pendientes para los Estados y las organizaciones de comercio, la unificación de las normas internacionales en cuanto a la protección de quién contrata (siendo Internet un mercado global se requieren soluciones globales ${ }^{38}$ ) y la determinación de las reglas de conflicto en la normativa por aplicar, y en la jurisdicción ${ }^{39}$, -sobre todo al esclarecimiento del lugar de conclusión del contrato ${ }^{40}$-, resaltando las circunstancias de inseguridad jurídica para todos los actores de la contratación. Sumado el hecho de que en el contrato electrónico, los medios virtuales adquieren un papel determinante como vía para el establecimiento de las relaciones contractuales, para la ejecución de los compromisos y para la prestación de los servicios

38 Aunque en el ámbito europeo, el tema de la jurisdicción en la contratación electrónica entre B2C está resuelta. El reglamento de Bruselas I, en su artículo 15 a 17 establece un sistema cerrado de competencia con la meta de la protección del consumidor. Un empresario que saca provecho del tráfico internacional de sus productos debe soportar el riesgo de un eventual proceso judicial en el extranjero y de la aplicación de un derecho extranjero. Si no quiere asumir este riesgo, tendría que limitar su ámbito de negocio mediante una configuración inequívoca de su página web. Si acepta no obstante un encargo con independencia de donde venga, entonces no se le genera ninguna injusticia por el hecho de tener que seguir un proceso en el extranjero. Véase Leible (2008).

39 En los contextos electrónicos desaparecen o por lo menos se diezman los conceptos de territorialidad, proximidad física y comunidad geográfica, lo que se traduce en el cuestionamiento del empleo de la normatividad territorial jerárquica producto de la soberanía estatal. Esta situación contribuye a erosionar el alcance de las técnicas localizadoras paradigmáticas del derecho internacional privado y facilita la toma en consideración de procesos de creación de normas de base no geográfica en el marco de mecanismos de autorregulación con la implicación de los actores relevantes. Véase De Miguel (2005).

40 Esta materia se encuentra regulada de diversa forma en la mayoría de los Estados, por ello la importancia del mercado interior europeo. Según la opinión de los órganos europeos son problemáticas sobre todo las diferencias entre los preceptos estatales así como la mismos, y en donde se acentúan aún más, las diversas asimetrías presentes en la contratación a distancia.

Conscientes de lo dicho, los legisladores encuentran en las obligaciones de información, ${ }^{41}$ un mecanismo de transmisión de información básica para la celebración de contratos queridos, y desarrollan una función de advertencia frente a los sujetos que intervienen de acuerdo con las realidades descritas, tratando de acotar, así, las desigualdades propias de esta nueva contratación.

Así entonces, es incuestionable la importancia que ha adquirido en la época actual, el denominado "derecho a ser informado", que le asiste al consumidor cada vez que pretende adelantar una relación de consumo. Si ubicamos su importancia dentro de las fases del iter contractual, vamos a hallar que desde la formación del contrato, el consumidor requiere de una correcta, completa

inseguridad jurídica referente a las reglas nacionales aplicables respectivamente a los servicios de la sociedad de la información. Considerando 5 de la directiva sobre el comercio electrónico. Al respecto afirma Leible (2008) que "La Comunidad Europea intenta solucionar este problema esencialmente de dos maneras: armonizando el derecho material y perfeccionando el derecho internacional privado. En el campo del derecho civil material tienen sobre todo especial importancia los siguientes actos jurídicos: la directiva sobre el comercio electrónico; la directiva por la que se establece un marco comunitario para la firma electrónica; la directiva relativa a la protección de los consumidores materia de contratos a distancia y la directiva relativa a la comercialización a distancia de servicios financieros destinados a los consumidores. Estas directivas regulan, claro está, solamente parcelas del derecho civil. Muchas conducen además solo a una armonización mínima, por lo que el derecho internacional privado mantiene aún su significado".

41 En la relación de consumo, atrás queda el debate de principios del siglo pasado en el ámbito de si se está frente a un deber. Hoy, es de aceptación pacífica la creencia de que es una verdadera obligatio al poderse identificar en ella, en su origen, causa, objeto, naturaleza y limites, los elementos propios de las obligaciones modernas. Véase Monsalve (2011). Posibilidad que en su momento había planteado Pérez (1990), quien catalogó a la información como un subprincipio del ordenamiento jurídico. Véase Alpa (1981), De Mauro y Fortinguerra (2002) y Demoulin y Montero (2002). 
y eficaz información que le permita establecer la conveniencia o no del mismo (Monsalve, 2008). Se reconoce que la obligación de información es aquel vínculo jurídico propio de las relaciones de consumo que tiene un deudor (profesional) para con un acreedor (consumidor o usuario) cuya prestación contiene una causa y un objeto delimitado exigible en diversas etapas del iter contractual, en especial, en la fase de formación del contrato como un presupuesto del consentimiento y en la etapa de ejecución contractual como elemento anexo del cumplimiento de la prestación principal. Sus fuentes legales son autónomas, constituyendo un derecho subjetivo de crédito. Generalmente, es el proveedor el deudor de la información, y el consumidor el acreedor del derecho en las tres etapas del iter contractual (Orti, 1992) ${ }^{42}$.

No en vano se considera en la actualidad, que la protección del consentimiento del consumidor se hace por medio de las obligaciones de información, del formalismo del contrato electrónico (sobre el que hablaremos luego) y a través del período de reflexión (donde se puede proceder al retracto).

Las obligaciones precontractuales de información en la contratación electrónica. A la luz de las directivas sobre comercio electrónico y los contratos negociados a distancia.

Al interior de la Unión Europea, el incentivar los mercados desde la creación de marcos que generaran confianza, fiabilidad y protección entre los intervinientes (vendedores-compradores), ha sido una preocupación, incluso, desde los años setenta del siglo pasado. Prueba de ello es la resolución del Consejo del 14 de abril de 1975 relativa a un "Programa preliminar de la Comunidad Económica Europea para una política de protección e información de los consumidores" donde se

42 En este mismo sentido Llobet (1996), al afirmar que la información en la etapa de formación del contrato es un elemento de conocimiento suministrado obligatoriamente por una de las partes contratantes (deudor de la obligación de información), a la otra parte hace hincapié en la necesidad de proteger a los compradores de bienes o de servicios contra la solicitud de pago de mercancías no encargadas y contra los métodos de venta agresivos.

Esta iniciativa tendría una manifestación posterior en la comunicación de la Comisión al Consejo "Nuevo impulso a la política de protección de los consumidores" (resolución del Consejo de 23 de junio de 1986), la resolución del Consejo de 9 de noviembre de 1989, sobre "Futuras prioridades para el relanzamiento de la política de protección del consumidor", y el "Plan trienal de acción para la política de protección de los consumidores en la CEE" (1990-1992), que preveía una directiva en esta materia.

Sin embargo, el primer paso legislativo importante en la protección de los consumidores en este medio, viene de la mano de la directiva (7/1997 de 20 de mayo) sobre protección de los consumidores respecto a los contratos negociados a distancia. Esta directiva se adopta con base en el artículo $100^{\mathrm{a}}$ del Tratado de la Comunidad Europea, lo que implica que (considerandos 1 a 3): la venta a distancia se configura como un servicio más, siendo indispensable para el buen funcionamiento del mercado interior que los consumidores puedan dirigirse a una empresa fuera de su país. La directiva pretende, armonizar las legislaciones nacionales (art. 1) de los Estados miembros, estableciendo un conjunto de normas mínimas y de contenido inderogable para el consumidor (arts. 12 y 14), en ella además se incluyen en el artículo 4, la información previa que debe entregarse al consumidor, en la que resalta la información concerniente a identificación del vendedor y del negocio por celebrarse. Debido a que no hay cambios relevantes en la materia con la directiva del comercio electrónico y siendo un asunto no reglado en la codificación decimonónica (Monsalve, 2008) haremos un análisis al respecto.

(acreedor de la obligación de información), teniendo como objeto principal la adecuada formación del consentimiento contractual de este último, tanto en lo referente a los aspectos jurídicos como materiales del negocio. 
El artículo cuarto de la directiva 7/1997, consagra que previamente a la celebración de cualquier contrato a distancia y con antelación necesaria, el consumidor

(...) deberá disponer de una información previa caracterizada por versar sobre las cualidades y calidades de los productos ofertados, sobre el precio y sobre las condiciones generales (como requisito de validez), es decir sobre los elementos esenciales y consustanciales del contrato (De Moulin \& Montero, 2002, p. 734).

La cual podrá complementarse ${ }^{43}$, si es del caso, por los Estados miembros de acuerdo con las competencias compartidas que regulan los asuntos de los consumidores.

Dentro del proceso evolutivo de los marcos normativos generales, vendría luego la directiva $31 / 2000$ sobre el comercio electrónico ${ }^{44}$, la cual como lo habíamos expresado, desarrolló y consolidó los niveles de protección en el mercado interior a distancia de los consumidores, y consagró importantes principios tuitivos aplicables a los contratos electrónicos, con altas cargas de transmisión informativa, caracterizadas, por la instantaneidad en cuanto a su transmisión, facilidad de acceso y claridad en cuanto a la forma como debe presentarse (De Moulin \& Montero, 2002).

En el ámbito nacional el Decreto. 3466/1982 (Estatuto del Consumidor), simplemente no regulaba los contratos entre ausentes, y mu-

43 En el ámbito español existen diversas normas sobre la materia, entre otras, artículos 27 y 28 LSSICE, artículos 60 y 97 Ley General de Defensa para los Consumidores y Usuarios (texto refundido de la LGDCU y otras leyes complementarias aprobado mediante Real Decreto (legislativo 1/2007); y artículos 7 a 9 de la ley 22/2007 sobre comercialización a distancia. Desistimiento en los contratos celebrados a distancia, entre los que ocupan un lugar destacado los contratos electrónicos (arts. 68 a 79, 101 y 102 LGDCU, art. 10 ley 22/2007, entre otros) de servicios financieros con destino a los consumidores, que incorporan los artículos 3 a 5 de la directiva 65/2002/CE, así como cho menos los supuestos de la contratación electrónica; laguna normativa que se suple con la entrada en vigencia del NEC (12 de abril de 2012), el cual recoge niveles de protección y principios tuitivos muy similares a las directivas en mención como veremos.

\section{El contenido de la obligación de información precontractual}

Comencemos entonces por recordar la importancia y el contenido de la obligación precontractual de información, haciendo un especial énfasis en la directiva (7/1997 de 20 de mayo) sobre protección de los consumidores respecto a los contratos negociados a distancia, al ser la primera en ocuparse de la materia en la contratación entre ausentes ${ }^{45}$. Desde lo metodológico, les recordamos a los lectores, que haremos uso de las normativas españolas en lo que adicione o desarrolle las directivas comunitarias.

No olvidemos que gracias a la información precontractual las partes podrán evaluar de antemano las posibilidades técnicas y económicas, de conveniencia del contrato o acuerdo que se pretende celebrar, en relación con los propósitos que cada sujeto aspira alcanzar; en otras palabras, si el contrato (futuro posible) es o no apropiado para satisfacer la necesidad que llevó a la parte a entablar contactos y a aceptar o no, las ofertas mercantiles con vistas a concluir si es o no beneficioso el potencial acuerdo contractual. Dentro del ámbito de las obligaciones de información es evidente que ellas tienen como eje central el anterior objetivo,

las que atribuyen imperativamente al consumidor un derecho de desistimiento. El RD 1906/1999 por el que se regula la contratación telefónica o electrónica con condiciones generales.

44 En el ámbito de los contratos electrónicos, siendo estos una modalidad de la contratación a distancia, tienen de igual forma aplicación complementaria las normas de la directiva 7/1997. Idéntica situación quedó incorporada en el NEC.

45 Transposición que se hizo en el caso español por medio de la ley 47/2002 de 19 de diciembre, la cual a su vez reformó la ley 7/1996 de 15 de enero, de ordenación del comercio minorista. 
no obstante frente a la situación concreta de la contratación entre personas distantes y con miras a disipar la incertidumbre de la no presencialidad o difícil ubicación del expendedor o fabricante, el marco normativo comunitario incluiría la plena identificación del experto dentro del ámbito de las cargas informativas previas.

Así entonces, manda la directiva 7/1997 que deberá suministrarse la identidad del proveedor ${ }^{46}$ (en caso de contratos que requieran el pago por adelantado, su dirección), las características esenciales del bien o del servicio, el precio del bien o del servicio, incluidos todos los impuestos; los gastos de entrega, en su caso, modalidades de pago, entrega o ejecución, existencia de un derecho de resolución ${ }^{47}$, costo de la utilización de la técnica de comunicación a distancia cuando se calcule sobre un soporte distinto de la tarifa básica, plazo de validez de la oferta o del precio; cuando sea procedente, la duración mínima del contrato, cuando se trate de contratos de suministro de productos a servicios destinados a su ejecución permanente o repetida.

En el ámbito nacional el NEC en el capítulo $V$ del título VII, que regula las ventas que utilizan métodos no convencionales o a distancia, consagra la misma estructura y componentes descritos, respecto a la información de identificación plena del proveedor del contenido contractual (que

46 En el caso de comunicaciones telefónicas, deberá precisarse explícita y claramente al principio de cualquier conversación con el consumidor la identidad del proveedor y la finalidad comercial de la llamada, así lo dispone el numeral 3 del artículo cuarto en la normativa en análisis.

47 Salvo en los casos mencionados en el apartado 3 del artículo 6.

48 El NEC consagra el capítulo VI a la protección del consumidor electrónico, por tanto, a pesar de regular las ventas a distancia en el capítulo $\mathrm{V}$, estas solo serán de aplicación complementaria, vía principio de especialidad. Siguiendo la estructura que plantean las dos normativas en comento, clasificaremos las obligaciones de información previa y poscontrato (aunque no se agrupan en título alguno en el texto). Como previas se destaca que los proveedores y expendedores (como denomina en este caso a los prestadores del servicio según la normativa europea), ubicados en el territorio nacional que ofrezcan productos con empleo de medios electrónicos, deberán (art. 50): "a) Informar en todo momento de forma cierta, no deja de ser totalmente novedoso para el panorama nacional), incluso, haciendo mayor énfasis en la cantidad y suficiencia de información (técnica entendible al no existir otra regulación que se ocupe de la materia. En todo caso si comparamos lo inserto en la normativa nacional con el acervo comunitario de la directiva 7/1997 no hay novedad alguna $)^{48}$.

En el ámbito de la claridad de la información que debe suministrarse la directiva 7/1997, enuncia en el numeral segundo del artículo cuarto que debe ser inequívoca, y que deberá facilitarse al consumidor de modo claro y comprensible, a través de cualquier medio adecuado, con la técnica de comunicación a distancia utilizada. Dejando claro, una obligación de resultado tendiente a que el consumidor deberá tener conciencia y además fiarse de la veracidad y suficiencia de la información recibida. De idéntica naturaleza y descripción en el NEC ${ }^{49}$.

Remata el artículo 4 de la directiva 7/1997 que la información suministrada deberá respetar, en particular, los principios de buena fe en materia de transacciones comerciales (haciendo relación a la buena fe objetiva), así como a los principios de protección de quienes sean incapaces de contratar según la legislación nacional de los diferentes Estados miembros.

fidedigna, suficiente, clara, accesible y actualizada su identidad especificando su nombre o razón social, Número de Identificación Tributaria (NIT), dirección de notificación judicial, teléfono, correo electrónico y demás datos de contacto. b) Suministrar en todo momento información cierta, fidedigna, suficiente, clara y actualizada respecto de los productos que ofrezcan. En especial, deberán indicar sus características y propiedades tales como el tamaño, el peso, la medida, el material del que está fabricado, su naturaleza, el origen, el modo de fabricación, los componentes, los usos, la forma de empleo, las propiedades, la calidad, la idoneidad, la cantidad, o cualquier otro factor pertinente, independientemente que se acompañen de imágenes, de tal forma que el consumidor pueda hacerse una representación lo más aproximada a la realidad del producto. También se deberá indicar el plazo de validez de la oferta y la disponibilidad del producto. En los contratos de tracto sucesivo, se deberá informar su duración mínima [...]".

49 Así artículo 50 y siguientes. 
El NEC no consagra normas sobre la buena fe objetiva como sustento de la obligación de informar, no obstante sí contiene el principio de especial protección de los menores ${ }^{50}$.

\section{La información poscontrato}

Plantea el artículo 5 de la directiva 7/1997, que el consumidor deberá recibir una confirmación por escrito o mediante cualquier otro soporte duradero a su disposición de la información mencionada en las letras a) a f) del apartado 1 del artículo $4^{51}$, a su debido tiempo durante la ejecución del contrato y, a más tardar, en el momento de la entrega cuando se trate de bienes, a menos que se haya facilitado ya la información al consumidor antes de la celebración del contrato, bien sea por escrito o sobre cualquier otro soporte duradero disponible que sea accesible para él ${ }^{52}$. En todo

50 Artículo 52: "Protección de los niños, niñas y adolescentes en comercio electrónico. Cuando la venta se haga utilizando herramientas de comercio electrónico, el proveedor deberá tomar las medidas posibles para verificar la edad del consumidor. En caso de que el producto vaya a ser adquirido por un menor de edad, el proveedor deberá dejar constancia de la autorización expresa de los padres para realizar la transacción".

51 "[...] a) identidad del proveedor y, en caso de contratos que requieran el pago por adelantado, su dirección; b) características esenciales del bien o del servicio; c) precio del bien o del servicio, incluidos todos los impuestos; d) gastos de entrega, en su caso; e) modalidades de pago, entrega o ejecución; f) existencia de un derecho de resolución, salvo en los casos mencionados en el apartado 3 del artículo 6 [...]".

52 No obstante el numeral segundo del artículo 5 menciona: "Lo dispuesto en el apartado 1 no se aplicará a los servicios cuya ejecución se realice utilizando una técnica de comunicación a distancia, cuando estos se presten en una sola vez, y cuya facturación sea efectuada por el operador de técnicas de comunicación. No obstante, el consumidor, en cualquier caso, deberá estar en condiciones de conocer la dirección geográfica del establecimiento del proveedor donde puede presentar sus reclamaciones".

53 Consagra el artículo 6 que: "respecto a todo contrato negociado a distancia, el consumidor dispondrá de un plazo mínimo de siete días laborables para rescindir el contrato sin penalización alguna y sin indicación de los motivos. El único gasto que podría imputarse al consumidor es el coste directo de la devolución de las mercancías al proveedor".

54 El artículo 50 literal h) consagra: "Salvo pacto en contrario, el proveedor deberá haber entregado el pedido a más tardar en el plazo de treinta (30) días calendario a partir del día siguiente a aquel en que el consumidor le haya comunicado su pedido. En caso de no encontrarse disponible el producto objeto del caso, deberá facilitarse: información escrita sobre las condiciones y modalidades de ejercicio del derecho de resolución ${ }^{53}$, la dirección geográfica del establecimiento del proveedor donde el consumidor puede presentar sus reclamaciones; información relativa a los servicios posventa y a las garantías comerciales existentes; en caso de celebración de un contrato de duración indeterminada o de duración superior a un año, las condiciones de rescisión del mismo.

Por su parte, el NEC consagra que deberá suministrarse información (no por escrito) por el medio por el que se está efectuando la contratación de diversos aspectos entre la forma que se dispone para el pago, tiempo de entrega y prestación del servicio $^{54}$; el derecho de retracto ${ }^{55}$ y su procedimiento para ejercerlo ${ }^{56}$; y un procedimiento para

pedido, el consumidor deberá ser informado de esta falta de disponibilidad de forma inmediata. En caso de que la entrega del pedido supere los treinta (30) días calendario o que no haya disponible el producto adquirido, el consumidor podrá resolver o terminar, según el caso, el contrato unilateralmente y obtener la devolución de todas las sumas pagadas sin que haya lugar a retención o descuento alguno. La devolución deberá hacerse efectiva en un plazo máximo de treinta (30) días calendario".

55 Artículo 50: "[...] c) Informar, en el medio de comercio electrónico utilizado, los medios de que disponen para realizar los pagos, el tiempo de entrega del bien o la prestación del servicio, el derecho de retracto que le asiste al consumidor y el procedimiento para ejercerlo, y cualquier otra información relevante para que el consumidor pueda adoptar una decisión de compra libremente y sin ser inducido en error".

56 Que en el caso será de 5 cinco días hábiles. El artículo 47 reza: "Retracto. En todos los contratos para la venta de bienes y prestación de servicios mediante sistemas de financiación otorgada por el productor o proveedor, venta de tiempos compartidos o ventas que utilizan métodos no tradicionales o a distancia, que por su naturaleza no deban consumirse o no hayan comenzado a ejecutarse antes de cinco (5) días, se entenderá pactado el derecho de retracto por parte del consumidor. En el evento en que se haga uso de la facultad de retracto, se resolverá el contrato y se deberá reintegrar el dinero que el consumidor hubiese pagado. El consumidor deberá devolver el producto al productor o proveedor por los mismos medios y en las mismas condiciones en que lo recibió. Los costos de transporte y los demás que conlleve la devolución del bien serán cubiertos por el consumidor. El término máximo para ejercer el derecho de retracto será de cinco (5) días hábiles contados a partir de la entrega del bien o de la celebración del contrato en caso de la prestación de servicios (...) [...]". 
la recepción y seguimiento de quejas ${ }^{57}$; dejando de lado, el hecho de informar al consumidor sobre las garantías que gozan los bienes y servicios ofertados, situación lamentable, sobre todo en un país donde el derecho en consumo comienza a fortalecerse ${ }^{58}$. Por último, cabe resaltar cómo el NEC consagra una norma de contenido contractual que afecta los contratos electrónicos de larga duración y sus prórrogas. Al prohibir el silencio como manifestación del consentimiento ${ }^{59}$, lo que dará fin -por lo menos en el ámbito nacional-a prácticas abusivas amparadas en el olvido de los consumidores de no informar su deseo de no continuidad en una fecha concreta.

La directiva 31/2000 sobre comercio electrónico Desarrolló diversas obligaciones de información incluso adicionales a las ya reguladas en la Directiva 7/1997 con un objetivo básico,

[...] establecer en relación con esos aspectos un marco jurídico que asegure a los consumidores en el entorno digital una posición equivalente a la que es típica de la contratación de consumo en el marco físico tradicional ${ }^{60}$. Ese marco normativo no solo es clave para hacer posible una tutela adecuada de los consumidores, sino que también puede resultar determinante para el desarrollo del comercio electrónico, tradicionalmente lastrado por la incertidumbre asociada a la contratación en el entorno virtual (De Miguel, 2008, p. 24).

57 Artículo 50. : “[...] g) Disponer en el mismo medio en que realiza comercio electrónico, de mecanismos para que el consumidor pueda radicar sus peticiones, quejas o reclamos, de tal forma que le quede constancia de la fecha y hora de la radicación, incluyendo un mecanismo para su posterior seguimiento. (...)[...]".

58 No obstante el NEC, consagra de forma novedosa ya no una garantía mínima presunta (regulada en el Dc. 3466/1982) que excluía diversos productos, sino una garantía legal en todos los productos. Para mayor información véase artículo 7 y siguientes del NEC.

59 Artículo 50: “[...] d) Queda prohibida cualquier disposición contractual en la que se presuma la voluntad del consumidor o que su silencio se considere como consentimiento, cuando de esta se deriven erogaciones u obligaciones a su cargo"

60 Como se ha destacado, en el caso de la contratación electrónica, "la confianza del consumidor parece un requisito previo e imprescindible para el pleno desarrollo del comercio electrónico y de la sociedad de la información, por lo que resulta clave garantizar
La directiva impuso dos tipos de obligaciones de información a los prestadores de servicios, cuyos benefactores serán los destinatarios del servicio y las autoridades competentes ${ }^{61}$. Por una parte una información general, de identificación a fin de acceder con facilidad y de forma directa $y$ permanente a identificar al oferente, $y$ por otra, información negocial dirigida a regular dos momentos concretos: el perfeccionamiento del contrato y la ejecución de las prestaciones debidas.

\section{La información general exigida}

Además de los requisitos estudiados de la directiva 7/1997 sobre comercio electrónico, plantea que los destinatarios del comercio electrónico puedan acceder con facilidad, gratuitamente y de forma directa al nombre del prestador ${ }^{62} y$ su ubicación en una dirección geográfica donde está establecido el prestador de servicios, y de manera novedosa, consagra la obligación del prestador de facilitar un medio de comunicación rápido y directo de comunicación, incluyendo su dirección de correo electrónico (art. 5.c).

A su vez, obliga al prestador de servicios (art. 5.d) a informar sobre su estado de inscripción en el registro mercantil u otro registro público similar, indicando el nombre de dicho registro, el número de inscripción, u otros medios equivalentes de identificación. Incluso si la actividad que ejerce se encuentra regulada ${ }^{63}$ o sometida a un régimen de autorización, deberá darse fe de ello así como

que el nivel de protección de sus intereses en el entorno telemático será, como mínimo, equivalente al existente en el mundo físico" (Diez, 2008, p. 62).

61 Aunque en el caso son diversas las leyes que ya tenían consagrado en diversos numerales obligaciones precontractuales de información y de identificación negocial, al respecto la ley 7/1996, LOCM, junto con su ley modificadora, ley 47/2002. De igual modo la LGDCU en sus artículos 8.1, 2 y 44.5 de la LOCM.

62 En el caso español la LSSICE, introdujo en su artículo 9, el nombre de dominio con el que el prestador se identifica en Internet.

63 Consagra el literal f) del artículo 5 de la directiva sobre comercio electrónico en lo que se refiere a las profesiones reguladas: "si el prestador de servicios pertenece a un colegio profesional o institución similar, datos de dicho colegio o institución, título profesional expedido y el Estado miembro en que se expidió, referencia a las normas profesionales aplicables en el Estado miembro de establecimiento y los medios de acceder a las mismas". 
los datos de la autoridad de supervisión correspondiente (art. 5.e $)^{64}$. Similares obligaciones informativas se consagran en torno al régimen tributario (IVA), al reseñarse obligatoriamente el número de identificación ${ }^{65}$. En cuanto a los precios remata el artículo 5.2 que ellos deben indicar claramente y sin ambigüedades, y se haga constar en particular, si se incluyen los impuestos y los gastos de envío ${ }^{66}$.

Según el NEC, se establecen los mismos principios de identificación, veracidad, claridad y accesibilidad como ya lo habíamos enunciado, inclusive, los de identificación tributaria (NIT) y los de la especificación del precio final de los productos ${ }^{67}$, empero, no se consagraron las obligaciones de informar el registro mercantil o registro público similar, ni tampoco si la actividad se encuentra especialmente regulada. Situación que se echa de menos, ya que en Colombia las cámaras de comercio no comparten un sistema de información unificado de sus registros públicos y, por ende, no es del todo fácil acceder a la información que sí considera como fundamental la directiva comunitaria. Sin embargo, el NEC consagra que si el proveedor o expendedor dan a conocer su membresía o afiliación en algún esquema de autorregulación o asociación o certificación empresarial, deberá facilitarles a los consumidores la verificación de dicha información ${ }^{68}$.

\section{La obligación de información previa}

Dejando a un lado la información del prestador del servicio, la sección segunda de la directiva

64 La LSSICE en su artículo 18.3, novedosamente introdujo que el prestador del servicio deberá informar los códigos de conducta a los que en su caso esté adherido y la manera de consultarlos vía electrónica.

65 Consagra: "g) si el prestador de servicios ejerce una actividad gravada por el impuesto sobre el valor añadido (IVA), el número de identificación a que hace referencia el apartado 1 del artículo 22 de la Sexta Directiva (77/388/CEE) del Consejo, de 17 de mayo de 1977, en materia de armonización de las legislaciones de los Estados miembros relativas a los impuestos sobre el volumen de negocios. Sistema común del Impuesto sobre el Valor Añadido: base imponible uniforme".

66 En el ámbito de la contratación por medio electrónico el NEC consagra en el artículo 26 parágrafo $2^{\circ}$ que "La Superintendencia de Industria y Comercio determinará las condiciones mínimas bajo las cuales operará la información pública de precios de los productos que se ocupa de las obligaciones precontractuales de contenido negocial en sus diversos aspectos (publicidad, ofertas, comunicaciones), las cuales denomina "comunicaciones comerciales". Y plantea en el artículo 6, que además de las normas comunitarias vigentes, todas las comunicaciones deberán, en la sociedad de la información, consagrarse en ellas: identificaciones claras sobre su naturaleza comercial (cuando lo sean), datos sobre la persona física o jurídica en nombre de la cual se hagan dichas comunicaciones comerciales; la claridad, accesibilidad, condicionalidad e inequivocidad de las ofertas promocionales y de los concursos o juegos promocionales. En conclusión, las normas de la directiva apuntan a que el consumidor reciba dos informaciones relevantes: el carácter comercial de la comunicación y el nombre o identidad de la persona que la realiza.

Complementa lo anterior la directiva, en el artículo 10, cuando consagra que el prestador de servicios debe facilitar al menos la siguiente información de manera clara, comprensible e inequívoca y antes de que el destinatario del servicio efectúe un pedido ${ }^{69}$ :

a) los diferentes pasos técnicos que deben darse para celebrar el contrato; b) si el prestador de servicios va a registrar o no el contrato celebrado, y si este va a ser accesible; c) los medios técnicos para identificar y corregir los errores de introducción de datos antes de efectuar el pedido; $[y]$ d) las lenguas ofrecidas para la celebración del contrato (Directiva 7/1997 sobre comercio electrónico).

se ofrezcan a través de cualquier medio electrónico, dependiendo de la naturaleza de este".

67 Artículo 50 literal c "[...] Igualmente deberá informar el precio total del producto incluyendo todos los impuestos, costos y gastos que deba pagar el consumidor para adquirirlo. En caso de ser procedente, se debe informar adecuadamente y por separado los gastos de envío".

68 Artículo 50, literal f: "[...] Cuando el proveedor o expendedor dé a conocer su membresía o afiliación en algún esquema relevante de autorregulación, asociación empresarial, organización para resolución de disputas u otro organismo de certificación, deberá proporcionar a los consumidores un método sencillo para verificar dicha información, así como detalles apropiados para contactar con dichos organismos, y en su caso, tener acceso a los códigos y prácticas relevantes aplicados por el organismo de certificación".

69 En el caso español el artículo 27 de la LSSICE hizo transcripción literal. 
Consagra dos salvedades que se caracterizan por un pacto en el que ambas partes no siendo consumidores así lo acuerden, y en los casos en los que el contrato nace mediante el intercambio de correos electrónicos u otra comunicación equivalente. Sin duda, las excepciones se encuentran consagradas en el plano de igualdad del que parte la directiva en los casos en mención, haciendo relación a la contratación entre profesionales (prestadores del servicio o incluso empresarios), y en el caso de la celebración por correo electrónico o por medios equivalentes, se reduce el riesgo de inseguridad jurídica en la medida que hay posibilidad de entablar un contacto comunicacional previo (tratos preliminares). Finaliza el artículo 10.3 con una obligación tendiente a los contratos con condiciones uniformes, indicando que estas deben estar disponibles de tal manera que el destinatario pueda almacenarlas y reproducirlas ${ }^{70}$.

Por su parte, el NEC no obliga al proveedor o expendedor a informarle a los consumidores sobre los pasos técnicos para culminar la contratación electrónica y para corregir los eventuales errores de digitación, no obstante, sí impone la obligación genérica de entregar la información relevante para que el consumidor pueda adoptar una decisión de compra libremente y sin ser inducido a error ${ }^{71}$.

70 El artículo 27.4 de la LSSICE y de conformidad con la ley 7/1998 sobre condiciones generales de la contratación y las reglas especiales que en la materia establece el RD 1906/1999 por el que se regula la contratación telefónica o electrónica con condiciones generales, el cual a su vez en el artículo 2 que antes de la celebración del contrato con una antelación necesaria al menos de tres días naturales a ella el predisponente deberá facilitar al adherente la información sobre todas y cada una de las cláusulas del contrato de modo veraz, eficaz y completo, y remitirle por cualquier medio adecuado a la técnica de comunicación a distancia utilizado, el texto de condiciones generales.

71 Artículo 50: "[...] c) Informar, en el medio de comercio electrónico utilizado, los medios de que disponen para realizar los pagos, el tiempo de entrega del bien o la prestación del servicio, el derecho de retracto que le asiste al consumidor y el procedimiento para ejercerlo, y cualquier otra información relevante para que el consumidor pueda adoptar una decisión de compra libremente y sin ser inducido en error".

72 El artículo 50 en su literal c, incluso consagra que: "[...] Queda prohibida cualquier disposición contractual en la que se presuma la voluntad del consumidor o que su
Sin embargo, con miras al cumplimiento de lo precedente, incluyó de forma novedosa (respecto a las directivas comunitarias) una obligación previa a la finalización o terminación de cualquier transacción de comercio electrónico, en la cual, el proveedor o expendedor, deberá presentar al consumidor un resumen del pedido de todos los bienes que pretende adquirir con su descripción completa, precios unitarios y costos de envío.

El propósito es que el adquiriente esté lo suficientemente informado, $y$ en su consentimiento se refleje su verdadera intención de adquisición libre de vicios, y de ser su deseo, hacer las correcciones que considere necesarias o la cancelación de la transacción ya que en todo "la aceptación de la transacción por parte del consumidor deberá ser expresa, inequívoca y verificable por la autoridad competente, por tanto el consumidor tiene el derecho de cancelar la transacción hasta antes de concluirla"72. Concluye la norma que dicho resumen deberá estar disponible para su impresión o descarga ${ }^{73}$, por ende, desde nuestro punto de vista, la norma nacional plantea un instrumento de protección mucho más efectivo que las comunitarias en mención.

Pero al contrario, no regula, infortunadamente, las comunicaciones comerciales, a pesar de que

silencio se considere como consentimiento, cuando de esta se deriven erogaciones u obligaciones a su cargo [...]".

73 Menciona el artículo 50 literal c que "[...] Previamente a la finalización o terminación de cualquier transacción de comercio electrónico, el proveedor o expendedor deberá presentar al consumidor un resumen del pedido de todos los bienes que pretende adquirir con su descripción completa, el precio individual de cada uno de ellos, el precio total de los bienes o servicios $y$, de ser aplicable, los costos y gastos adicionales que deba pagar por envío o por cualquier otro concepto y la sumatoria total que deba cancelar. Este resumen tiene como fin que el consumidor pueda verificar que la operación refleja su intención de adquisición de los productos o servicios ofrecidos y las demás condiciones, y de ser su deseo, hacer las correcciones que considere necesarias o la cancelación de la transacción. Este resumen deberá estar disponible para su impresión y/o descarga. La aceptación de la transacción por parte del consumidor deberá ser expresa, inequívoca y verificable por la autoridad competente. El consumidor debe tener el derecho de cancelar la transacción hasta antes de concluirla [...]". 
el fin tuitivo de protección frente a prácticas fraudulentas sí se consagra ${ }^{74}$. En principio, tal vacío se podrá suplir parcialmente con normas generales consagradas como derechos de los consumidores a recibir información precisa $e$ idónea de los productos que se ofrezcan ${ }^{75}$. Que en todo caso no será igual de efectiva de haber insertado obligaciones informativas concretas en todas las comunicaciones efectuadas en el comercio electrónico, haciéndose obligatorio la indicación, cuando fuera el caso, de la naturaleza comercial y así evitar la inducción a error tan común en estos medios ${ }^{76}$ (en donde mediante "obsequios", concursos, juegos y ofertas ${ }^{77}$ se captura la atención del cibernauta ${ }^{78}$ ) constatando en muchos casos que se está frente a una comunicación comercial después de varios clic (en el mejor de los casos) y luego de la pérdida de tiempo ${ }^{79}$.

74 Artículo 30: "Prohibiciones y responsabilidad. Está prohibida la publicidad engañosa. El anunciante será responsable de los perjuicios que cause la publicidad engañosa [...]".

75 "1.3. Derecho a recibir información: Obtener información completa, veraz, transparente, oportuna, verificable, comprensible, precisa e idónea respecto de los productos que se ofrezcan o se pongan en circulación, así como sobre los riesgos que puedan derivarse de su consumo o utilización, los mecanismos de protección de sus derechos y las formas de ejercerlos".

76 En lo que concierne a la publicidad, el NEC da un avance fundamental en la materia al incorporar de forma novedosa la fuerza vinculante de la publicidad. Consagra la norma: artículo 29: "Fuerza vinculante. Las condiciones objetivas y específicas anunciadas en la publicidad obligan al anunciante, en los términos de dicha publicidad". De seguro dicho artículo en su momento se desarrollará, delimitando el alcance de su indeterminación. De lo contrario, será caldo de cultivo para respaldar prácticas poco honestas por parte de los comerciantes al amparar sus acciones en hechos subjetivos.

77 Al respecto el NEC, consagra en el artículo 33: "Promociones y ofertas. Los términos de las promociones y ofertas obligan a quien las realice y estarán sujetas a las normas incorporadas en la presente ley. Las condiciones de tiempo, modo, lugar y cualquier otro requisito para acceder a la promoción y oferta, deberán ser informadas al consumidor en la publicidad. Sin perjuicio de las sanciones administrativas a que haya lugar, de no indicarse la fecha de iniciación de la promoción u oferta, se entenderá que rige a partir del momento en que fue dada a conocer al público. La omisión de la fecha hasta la cual está vigente o de
En este caso la identificación del origen de la comunicación es sinónimo de transparencia ${ }^{80}$, que entre otras justificaciones encuentra su razón de ser en la naturaleza de la Internet, donde la diversidad de medios que se usan para difundir la publicidad es evidente, y además, proclive al riesgo de confusión. El aviso permite diferenciar el mensaje comercial, del contenido puramente informativo; por ejemplo, que puede arrojar una página que esté consultando un usuario que se alista a efectuar una compra.

En cuanto al lenguaje de las transacciones, si bien el NEC específica en su parte general (aplicable a todas las relaciones de consumo) que por lo menos la información mínima de todos los productos debe estar en español ${ }^{81}$, guarda silencio en cuanto a los idiomas ofrecidas en los portales para la celebración de los contratos, situación

la condición de que es válida hasta agotar inventario determinado, hará que la promoción se entienda válida hasta que se dé a conocer la revocatoria de la misma, por los mismos medios e intensidad con que se haya dado a conocer originalmente.

78 No pocas son las campañas que por ejemplo la Federal Trade Commission ha abanderado en Estados Unidos controlando las ofertas escondidas (Comisión Federal de Comercio, s. f.). Para ver mas, http://www.ftc.gov/es

79 Para evitar lo anterior, en el caso español cuando estas comunicaciones comerciales se efectúen por correo electrónico u otro medio de comunicación electrónica equivalente, el remitente deberá incluir obligatoriamente al comienzo de cada mensaje la palabra "publicidad" $\mathrm{o}$, de acuerdo con la modificación introducida en el artículo 20 LSSICE con la LMISI, la abreviatura "Publi".

80 La doctrina belga encuentra diversas justificaciones en dicha obligación de identificación, en torno a la transparencia que debe estar presente en el comercio. Así por ejemplo se identifican tres elementos que la caracterizan: una identificación personal de quien elabora la comunicación comercial, el Estado que ha autorizado el anuncio o el sitio donde el prestatario ofrece la promoción, que en todo caso debe ser perfectamente identificable (condiciones y plazos) de forma clara e inequívoca (Barceló \& Montero, 2000).

81 Artículo 23: "Información mínima y responsabilidad. Los proveedores y productores deberán suministrar a los consumidores información, clara, veraz, suficiente, oportuna, verificable, comprensible, precisa e idónea sobre los productos que ofrezcan $y$, sin perjuicio de lo señalado para los productos defectuosos, serán responsables de todo daño que sea consecuencia de la inadecuada o insuficiente información. En todos los casos la información mínima debe estar en castellano". 
que no genera mayores complejidades (si el proveedor está ubicado físicamente en Colombia) en un país con un solo idioma oficial.

Respecto a las excepciones de la directiva del comercio electrónico, el NEC no hace diferenciación alguna en si el contrato nace por vía correo electrónico, o desde los portales, con fases o ventanas preestablecidas; por tanto, en principio, nuestra norma, regiría en cualquier tipo de transacción en la que se identifique una relación profesional-profano ${ }^{82}$, contrario al ámbito europeo.

\section{Las obligaciones poscontractuales}

La directiva sobre comercio electrónico consagra en el artículo 11.1 a $3^{83}$ (salvo cuando exista pacto entre no consumidores o por celebración del contrato vía correo electrónico) que en los casos en los que se efectúe su pedido por vía electrónica, se aplicarán los siguientes principios: (i) que el prestador de servicios debe acusar recibo del pedido del destinatario sin demora indebida y por vía electrónica, (ii) se considerará que se recibió el pedido y el acuse de recibo cuando las partes a las que se dirigen puedan tener acceso

82 Es importante precisar que el NEC, viene a clarificar una situación que no era diáfana conforme a quién podía entenderse por consumidor, ante la infortunada definición del Dc. 3466/1982, artículo 10, que definía: "c). Consumidor. Toda persona natural o jurídica, que contrate la adquisición, utilización o disfrute de un bien o la prestación de un servicio determinado, para la satisfacción de una o más necesidades. En la actualidad, la reciente norma plantea en su art. 5. 3. Consumidor o usuario. Toda persona natural o jurídica que, como destinatario final, adquiera, disfrute o utilice un determinado producto, cualquiera que sea su naturaleza para la satisfacción de una necesidad propia, privada, familiar o doméstica y empresarial cuando no esté ligada intrínsecamente a su actividad económica. Se entenderá incluido en el concepto de consumidor el de usuario". Por todo lo anterior, tendremos un ámbito de aplicación amplio del NEC en el que podrán ser considerados como consumidores, empresarios que realicen compras que no estén ligadas a su objeto social.

83 Así lo estipula el artículo 28 de la LSSICE.

84 Al respecto se planteó, si este requisito era un elemento de perfeccionamiento del contrato celebrado por vía electrónica. Al respecto Batuecas (2005), declara que por infortunio ni la directiva, ni la LSSICE regularon dicha circunstancia; sin embargo se decanta por afirmar que si el acuse no se realiza, efectivamente habrá un a los mismos $^{84}$, y (iii) poner a disposición del destinatario del servicio los medios técnicos idóneos, eficaces y accesibles que le permitan identificar y corregir los errores de introducción de datos, antes de realizar el pedido.

Lo anterior solo es aplicable siempre y cuando el contrato se haya perfeccionado, es decir, haya existido un encuentro entre la oferta y la aceptación. En el ámbito español la LSSICE, desarrolló el tiempo en el que se debe dar el acuse de recibo, planteando 24 horas posteriores a la celebración del contrato como plazo máximo del envío, idéntica situación en el campo nacional, donde además el NEC consagró ${ }^{85}$ que dicho acuse deberá contener información precisa del tiempo de entrega ${ }^{86}$, precio exacto, incluyendo los impuestos, gastos de envío y la forma en que se realizó el pago, a pesar de que todo eso había sido informado previamente $e^{87}$.

Por último, es importante resaltar, que aunque la directiva 31/2000 no consagró como una obligación poscontractual la obligación de transmitir información escrita sobre las condiciones y modalidades de ejercicio del derecho de resolución, esto es obligatorio en el ámbito europeo por

incumplimiento de contenido contractual, y por tanto procederán las acciones o de cumplimiento forzoso o de resolución en ambos casos acompañadas de la indemnización respectiva.

85 Artículo 50 literal d: "[...] Concluida la transacción, el proveedor y expendedor deberá remitir, a más tardar el día calendario siguiente de efectuado el pedido, un acuse de recibo del mismo, con información precisa del tiempo de entrega, precio exacto, incluyendo los impuestos, gastos de envío y la forma en que se realizó el pago [...]".

86 Que en ningún caso podrá ser superior a treinta días calendario so pena del ejercicio de resolución. Artículo 50: "[...] h) En caso de que la entrega del pedido supere los treinta (30) días calendario o que no haya disponible el producto adquirido, el consumidor podrá resolver o terminar, según el caso, el contrato unilateralmente y obtener la devolución de todas las sumas pagadas sin que haya lugar a retención o descuento alguno. La devolución deberá hacerse efectiva en un plazo máximo de treinta (30) días calendario [...]".

87 Artículo 50: "[...] d) Previamente a la finalización o terminación de cualquier transacción de comercio electrónico, el proveedor o expendedor deberá presentar al consumidor un resumen del pedido de todos los bienes que pretende adquirir con su descripción completa, el precio individual de cada uno de ellos [...]. 
mandato de la directiva 7/199788. Lo precedente como una garantía más que tendrá el consumidor, no obstante, las diversas cargas informativas que recaen sobre el prestador del servicio.

El NEC, al respecto, es más completo en cuanto a las obligaciones que recaen sobre el proveedor o expendedor, no solo plantea la obligación de confirmar acuse de correo ${ }^{89}$, sino que además le impone el deber de probar que la aceptación de la transacción ${ }^{90}$ por parte del consumidor fue expresa e inequívoca; a su vez, la forma en que se realizó el pago y la entrega real y efectiva de los bienes o servicios adquiridos, por un tiempo igual al que hay que almacenar los papeles de comercio $^{91}$.

Por último, el artículo $53^{92}$ del NEC, impone obligaciones de información entre profesionales (B2B), o incluso entre aquellos qué, no ejerciendo habitualmente el propietario del portal web deberá exigir a todos los oferentes, información que permita su identificación (como mínimo, el nombre o razón social, documento de identificación, dirección física de notificaciones y teléfonos), siendo los destinatarios de la información los consumidores (adquirentes) y la administración pública para eventuales reclamaciones o investigaciones.

88 En el caso español, está consagrada en la ley 47/2002 que introduce el artículo 47 de la LOCM. Para ver más en la doctrina Pacheco Cañete (2000), la protección del consumidor una vez perfecto el contrato en la venta de productos a distancia a través de Internet, la ley $5184 / 2000$.

89 Artículo 50. literal c: "[...] Concluida la transacción, el proveedor y expendedor deberá remitir, a más tardar el día calendario siguiente de efectuado el pedido, un acuse de recibo del mismo, con información precisa del tiempo de entrega, precio exacto, incluyendo los impuestos, gastos de envío y la forma en que se realizó el pago [...]".

90 De idéntica situación en el caso español. El artículo 5.1 del real decreto 1906/1999, de 17 de diciembre, establece que corresponde al predisponente, en los contratos realizados por vía telefónica, electrónica o telemática, "la carga de la prueba sobre la existencia y contenido de la información previa de las cláusulas del contrato; de la entrega de las condiciones generales; de la justificación documental de la contratación una vez efectuada; de la renuncia expresa al derecho de resolución; así como de la correspondencia entre la información, entrega y justificación documental y el momento de sus respectivos envíos".

91 "[...] e) Mantener en mecanismos de soporte duradero la prueba de la relación comercial, en especial de la
Luego de revisar los aportes de las dos directivas europeas y el NEC, se constata que la diferencia de la obligación de información consagrada en las diversas etapas del iter contractual radica en el contenido y fundamento teleológico. Así, en la primera fase, la información que debe transmitir el prestador del servicio va dirigida hacia la consecución de un consentimiento libre de vicios, al cual se pretende llegar por suficiencia y certeza (a pesar de la no presencia física de los intervinientes) con un alto componente informativo en cuanto a la identificacion del comerciante (sujeto), de su actividad y de su domicilio físico y bienes; y vía información negocial basándose en la comunicación del objeto, la causa y el vínculo contractual; la información radica en los elementos esenciales del contrato, en los requisitos que deben cumplirse a lo largo de la contratación, $y$ en aquellas circunstancias que a pesar de ser accidentales por sus diversas implicaciones jurídicas, económicas y volitivas, son de relevancia dentro del acto comunicacional ${ }^{93}$; por otra parte, ya en la etapa contractual, la información suministrada se encamina a confirmar con certeza la celebración y perfeccionamiento del acto.

Por tanto, el cumplimiento de las obligaciones de información no solo tendrían un efecto directo

identidad plena del consumidor, su voluntad expresa de contratar, de la forma en que se realizó el pago y la entrega real y efectiva de los bienes o servicios adquiridos, de tal forma que garantice la integridad y autenticidad de la información y que sea verificable por la autoridad competente, por el mismo tiempo que se deben guardar los documentos de comercio".

92 Artículo 53: "Portales de contacto. Quien ponga a disposición una plataforma electrónica en la que personas naturales o jurídicas puedan ofrecer productos para su comercialización y a su vez los consumidores puedan contactarlos por ese mismo mecanismo, deberá exigir a todos los oferentes información que permita su identificación, para lo cual deberán contar con un registro en el que conste, como mínimo, el nombre o razón social, documento de identificación, dirección física de notificaciones y teléfonos. Esta información podrá ser consultada por quien haya comprado un producto con el fin de presentar una queja o reclamo y deberá ser suministrada a la autoridad competente cuando esta lo solicite".

93 Caracterizado por la presencia de: (i) un emisor y un receptor, (ii) un canal (la manifestación de la voluntad y su forma, por ejemplo la exteriorización, (iii) un mensaje (el objeto del acto jurídico) y (iv) el contexto (la normativa que la rige, las circunstancias personales de tiempo, modo y lugar tanto del emisor como del receptor). Para mayor información véase Kraut (1996). 
en la validez y perfeccionamiento del acto, sino que será, a su vez, un criterio para valorar la observancia del estándar del debido y diligente comportamiento exigible al profesional ${ }^{94}$, de acuerdo con los mandatos de la buena fe objetiva ${ }^{95}$.

Pretenden las normas comunitarias y el NEC, que la utilización de medios electrónicos no tiene por qué generar reducción del caudal de información por transmitir a los consumidores, la cual debe ser clara ante todo, y de un modo concreto, digitalizada y ajustándose a las necesidades que ofrezca el medio o software (Batuecas, 2004).

Por otra, se aseguran los legisladores, que los consumidores deberán comprender la información electrónica, con una completa, exhaustiva e inequívoca descripción del bien o servicio, de la forma y duración de entrega o cumplimiento, evitando tecnicismos o incertidumbre en el consumidor y afianzando su confianza y participación en dichos mercados.

Aqune, como el proceso de la delimitación de la obligación de información es complejo, siempre

$94 \quad$ En ese mismo sentido Batuecas (2005) sostiene que la observancia de todos y cada uno de los deberes de información por parte del proveedor del producto se entenderá como la primera manifestación de su buena fe.

95 Al respecto sostiene Santarelli, (2009): "lo verdaderamente relevante es que la nota de profesionalidad debe transitar por el andarivel de la integración del acto en cuestión en una lógica de mercado, es decir es menester tener una visión de contexto de ese acto tal que esté inmerso dentro de una realidad de un proceso productivo o comercial [...]. Lo que pone en evidencia de este modo, el acento de objetivación en la apreciación del acto para ser caracterizado como involucrado en la actividad profesional" (p. 44).

96 En España diversas las leyes tanto estatales como autonómicas y reales decretos que consagran obligaciones pre y poscontractuales, solo por citar algunas. En todo, la LGDCU siendo el primer texto español que consagró dichos marcos normativos, el real decreto 515/1989 de 21 de abril sobre la obligación del vendedor de suministrar al comprador y al arrendatario de viviendas, ley 21/1995 sobre viajes combinados, la ley 42/1998 sobre tiempos compartidos, la ley 41/2002 reguladora de la autonomía del paciente y de derechos y obligaciones en materia de información y documentación clínica entre otras. Para un análisis general de cada una de estas normas, véase Reyes (2005).

97 Que en el caso español, con las leyes con las que se incorporaron las directivas en comento y que ya será necesario hacer un ejercicio integrador en la variada normatividad existente (en el ámbito comunitario y en el nacional) y que regula contratos en específico ${ }^{96}$, y de la situación particular negocial (cuyos parámetros siempre determinarán el objeto) en cada uno de los países miembros de la Unión para delimitar, adecuadamente, el alcance y las características ${ }^{97}$, en el cumplimiento del contenido que se le presupone. Para ello, es de suma utilidad acudir a los requisitos que debe reunir la información en todo acto de comunicación, sin importar su escenario y ámbito de aplicación. En este orden de ideas, la información en cualquier contrato debe ser: veraz, eficaz y suficiente (completa, detallada y precisa $)^{98}$ so pena de responder el expendedor de todo daño que se cause por la inadecuación o insuficiencia ${ }^{99}$. Ahora, lo que sucede es que en la contratación en línea, no basta con esto para materializar la eficacia de sus fines tuitivos; por ello es necesario que además, reúna tres atributos (sobre los que la normativa objeto de análisis hizo un discreto desarrollo que en su momento había la Federal Trade Commission ${ }^{100}$ advertido), por tanto, la información deberá ser útil, utilizable y usada ${ }^{101}$.

reseñamos, más la normativa que afecta la contratación a distancia, RD 1906/1999 por el que se regula la contratación telefónica o electrónica con condiciones generales y la que reglamenta la ordenación del comercio minorista (LOCM).

98 Tema sobre el que ya tuvimos oportunidad de manifestarnos con profundidad en Monsalve (2011).

99 Así lo establece novedosamente el NEC en el artículo 23: "Los proveedores y productores deberán suministrar a los consumidores información, clara, veraz, suficiente, oportuna, verificable, comprensible, precisa e idónea sobre los productos que ofrezcan y, sin perjuicio de lo señalado para los productos defectuosos, serán responsables de todo daño que sea consecuencia de la inadecuada o insuficiente información. En todos los casos la información mínima debe estar en castellano [...]". Por su parte el artículo 24 en su parágrafo consagra los eximentes a la regla anterior: "Parágrafo. El productor o el proveedor solo podrá exonerarse de responsabilidad, cuando demuestre fuerza mayor, caso fortuito o que la información fue adulterada o suplantada sin que se hubiera podido evitar la adulteración o suplantación".

100 La Comisión Federal de Comercio, en el ámbito norteamericano es el ente que se encarga de velar y proteger a los consumidores.

101 Para mayor información véase página web de la Comisión Federal de Comercio (s. f.) que está disponible en inglés y español. 
Útil cuando, por medio de ella, haya suficiencia informativa (adaptada a la situación particular de cada consumidor) y resuelva cualquier duda que se presente durante, o después del proceso de compra (por ello son tan útiles las listas de preguntas frecuentes). Utilizable, es decir, que en cualquier momento (incluso así no se celebre contrato alguno) pueda ser accesible por el adquirente. Y usada, que para acceder a ella, no exista un dificultoso proceso de hipervínculos y que además sea enviada (o esté disponible) de tal forma que se tenga al momento necesario de su requerimiento. Para lo anterior, resultan especialmente útiles los recursos de la tecnología multimedia (colores, animaciones, entre otros) con los que se puede llamar la atención del consumidor sobre los elementos importantes y relevantes del contrato, pero infortunadamente ocurre todo lo contrario en la práctica: se emplean dichas herramientas en la publicidad haciéndola llamativa e interesante, en cambio en la información contractual propiamente dicha, se utilizan los textos convencionales que hace su consulta aburrida y desapercibida. Pero sobre estos últimos puntos, inexistentes en la regulación, tanto europea como nacionalmente; esperamos en Colombia sea objeto de desarrollo en el proceso que le espera a la Superintendencia de Industria y Comercio (SIC) de reglamentación; que hasta ahora no se han surtido.

102 Bien es sabido que el fenómeno de las condiciones generales hace su irrupción en la Revolución Industrial, pero sería el sector servicios (Roppo, 1975) el que lo adoptó e impulsó llevándolo a la cúspide de la contratación masiva en la que se halla. No es de extrañar que Saleilles (1901) fuera el que se ocupara, por primera vez, del estudio de esta nueva forma contractual en los incipientes inicios del siglo XX. Recuérdese que dentro de la formación del contrato al antiguo director de la Revue Trimestrielle de Droit Civil, le preocupó novedosamente el tema de la ruptura de las negociaciones y sería él quien acuñara en la lengua francesa el término pourparlers, para denominar la ruptura injustificada de las negociaciones. Pero contrario a la suerte que corrieron sus estudios sobre los pourparlers en aquella época, sus preocupaciones y asertos sobre les contrats d'adhésion, y su uso cada vez más generalizado por los comerciantes, hicieron que sus hipótesis se divulgaran rápidamente en toda Europa.

103 No en vano por ejemplo Laffineur (2000) afirma que: "el consensualismo y la libertad de comercio han contribuido demasiado en la explotación del consumidor por los otros actores económicos, por tanto el derecho
Para concluir, las normas en estudio señalan unos requisitos mínimos que habrá que acatar por parte del prestador del servicio (en Europa) o el expendedor (en Colombia) al momento de cumplir con las obligaciones de información, pero cuyo contenido final estará fijado en cuanto a su suficiencia, por la actividad o servicio ofrecido, y por la idónea colaboración del consumidor (en la carga informativa que le asiste), ya que como lo sostuvimos aquí, la buena fe objetiva impone comportamientos recíprocos (Monsalve, 2011).

\section{UN INTENTO POR LA SUPERACIÓN DEL DÉFICIT DE INFORMACIÓN MEDIANTE EL REGRESO AL CONTRATO SOLEMNE. LAS CONDICIONES GENERALES DE LA CONTRATACIÓN ${ }^{102}$}

A pesar de las fuertes cargas informativas que caracterizan el contrato electrónico, el déficit informativo puede estar presente, por esto, una de las principales medidas paliativas son las de tipo coercitivo, y así, la vuelta al contrato solemne sin duda es una de ellas ${ }^{103}$, no en vano en la actualidad se afirma, desde el ámbito comunitario, sobre la existencia de une formalisme électronique légal ${ }^{104}$. En la materia la forma de cómo debe presentarse la información no se deja al juego de la autonomía de la voluntad

del consumo debe incorporar diversas exigencias formalistas que pongan freno a la velocidad con la que se celebran los contratos en la actualidad" (p. 237).

104 Según Mas (2005), se comenzó a usar esta denominación, en especial a la aprobación de los textos comunitarios de la directiva 7/1997/CE del 20 de mayo, concerniente a la protección de los consumidores en materia de contratos a distancia y la directiva 31/2000/ CE del 8 de junio, directiva sobre el comercio electrónico. Llamado de igual forma por Domont (1996), de acuerdo con la modalización de la comunicación cuyo beneficio recae directamente en el consumidor. Aunque encontramos por ejemplo que la doctrina belga viene utilizando dicho calificativo al interior del derecho de consumo, cuando con ocasión a la aprobación de la ley del 14 de julio de 1991 sobre las prácticas del comercio y sobre la información y protección al consumidor, se derogó el principio del consensualismo, al multiplicar las reglas de forma, al exigir formalismos informativos $y$ administrativo, al prever el uso de títulos (buena compra) para calificar el comportamiento del vendedor. Para mayor información, véase Fagnart (1988). 
como lo hemos visto. Así entonces, razón tiene Balluguera (2007) cuando afirma que el destino normal de la información precontractual es su incorporación al contrato, pero ya no de cualquier manera. Por tanto, en este ámbito, la información precontractual, indica, en cierto sentido, un contenido necesario del mismo.

Al respecto Martín (2001) manifiesta que muchas de las leyes de protección al consumidor tienen un denominador común, uno o más preceptos dedicados a regular los aspectos formales del contrato. Con los rótulos de "documentación del contrato", "forma y contenido del contrato", "forma y eficacia" o "contenido mínimo del contrato", llegando incluso el legislador a prever obligaciones formales sobre el empresario, que exigen que el mismo se realice por escrito, así como que contenga una serie de menciones obligatorias. Remata Martín (2001) afirmando que todo lo anterior ha generado una instrumentalización de la forma del contrato con unos fines tuitivos y, por ello, en muchas leyes relativas al consumo, queda patente un renacimiento del formalismo que busca proteger al consumidor a través del establecimiento de unas obligaciones formales para el empresario.

En la contratación electrónica, dicho formalismo está direccionado a ciertas partes del contrato, en primer lugar, hacia el consentimiento del consumidor (o incluso a cualquier contratante) libre y claro (De Nayer \& Laffineur, 2000) como beneficiario de diversas obligaciones de informa-

105 En la actualidad, la realidad económica y jurídica nos demuestran que un número cada vez mayor (sino la gran parte) de los contratos que se celebran, se hacen con la modalidad de las condiciones generales prerredactadas por el empresario, el profesional o los conglomerados económicos, que imponen a sus clientes cuando celebran sus contratos, sin posibilidad alguna de ser modificadas. De este modo, el contrato con negociación previa que determina (o suele determinar) un equilibrio de intereses entre las partes, aunque persiste en determinados ámbitos, tiende a desaparecer en otros sectores (seguros, banca, transporte marítimo y aéreo, y en general, en determinados tipos de servicios). Debido a ello, entre otras razones, se ha hablado, sobre todo a finales del siglo XX, de que el derecho contractual y obligacional tradicional se encuentra en crisis y necesitado de un reajuste (Serra, 2005). Pese a que su popularidad entre la industria y el sector servicios se debe entre otras muchas razones, a la reducción de los costos de transacción, en especial, a los de conclusión (por su ción con el fin de clarificar su voluntad cuando navega y concluye contratos en el ciberespacio (Mas, 2005). Por otra parte, se hace presente en la validez de las cláusulas con condiciones uniformes, en lo que respecta a su previo conocimiento. No obstante, lo anterior, nos permite afirmar que la validez del contrato celebrado por medios informáticos sigue sujetándose al consentimiento más que a la forma (Pérez, 2001).

La directiva del comercio electrónico, plantea unas exigencias relevantes del formalismo informativo específico en los contratos electrónicos, concernientes al período de formación del contrato. Las cuales se traducen en la obligación, que recae sobre el profesional que ofrece bienes y servicios, de comunicar a sus clientes potenciales diversa información completa, entendible y accesible (la identidad del vendedor, sobre la manera de modificar los datos de compra, la confirmación del pedido, entre otros) proporcionada por unos medios concretos y definida previamente por la ley (como lo hemos hasta aquí reseñado).

En los contratos con condiciones generales de la contratación, la directiva en mención ${ }^{105}$ (art. 10.3), indica unas especificidades de acceso, de manera tal que dichos clausulados deberán estar disponibles para que el destinatario pueda almacenarlos y reproducirlos. Por su parte, el NEC consagra que los contratos donde existan condiciones generales deben pasar por el cumplimiento de unos requisitos mencionados en el artículo 37106, entre ellos: haber informado

rapidez y uniformidad), y a los de ejecución (control de los compromisos, previsibilidad del cumplimiento); haciendo del contrato, una unidad de intercambio económico, y de control estándar o uniforme de riesgos, costos y beneficios.

106 "Condiciones negociales generales y de los contratos de adhesión. Las condiciones negociales generales y de los contratos de adhesión deberán cumplir como mínimo los siguientes requisitos: 1 . Haber informado suficiente, anticipada y expresamente al adherente sobre la existencia, efectos y alcance de las condiciones generales. En los contratos se utilizará el idioma castellano. La firma del consumidor sobre el documento que contiene el clausulado hará presumir salvo prueba en contrario, que esta información se produjo en la forma exigida en este artículo. 2. Las condiciones generales del contrato deben ser concretas, claras y completas. 3. En los contratos escritos, los caracteres deberán ser legibles a simple vista y no incluir espacios en blanco". 
sobre su existencia y alcance de forma expresa y previa, a su vez, dicho clausulado deberá estar fácilmente (y en todo momento) accesible, disponible $e^{107} y$ debe ser aceptado como requisito previo de validez ${ }^{108}$. A su vez, establece que las condiciones deberán ser concretas, claras y completas ${ }^{109}$, por tanto, ellas deberán ser leíbles (ya los tribunales se oponen a las letras microscópicas o reproducidas con sistemas de bajo contraste), escritas en el idioma del consumidor para su cabal entendimiento y donde se utilicen palabras de uso común. Por último, se determina que las cláusulas no podrán afectar el equilibrio contractual, de lo contrario, se considerarán como inexistentes ${ }^{110}$ (control de contenido).

En el caso español, no solo son exigibles las obligaciones de información sobre las condiciones generales de la contratación (y su aceptación) ${ }^{111}$ sino que impone al empresario predisponente, la obligación de remitir el texto completo de esas condiciones $^{112}$. Lo cual evita que en el futuro

107 Artículo 50: "[...] d) Publicar en el mismo medio y en todo momento, las condiciones generales de sus contratos, que sean fácilmente accesibles y disponibles para su consulta, impresión y descarga, antes y después de realizada la transacción, así no se haya expresado la intención de contratar [...]".

108 Artículo 39: "Constancia de la operación y aceptación. Cuando se celebren contratos de adhesión, el productor y/o proveedor está obligado a la entrega de constancia escrita y términos de la operación al consumidor a más tardar dentro de los tres (3) días siguientes a la solicitud. El productor deberá dejar constancia de la aceptación del adherente a las condiciones generales. El Gobierno Nacional reglamentará las condiciones bajo las cuales se deberá cumplir con lo previsto en este artículo".

109 Artículo 37.2. "[...] Las condiciones generales del contrato deben ser concretas, claras y completas. 3 . En los contratos escritos, los caracteres deberán ser legibles a simple vista y no incluir espacios en blanco [...]".

110 Artículo 42: "Concepto y prohibición. Son cláusulas abusivas aquellas que producen un desequilibrio injustificado en perjuicio del consumidor y las que, en las mismas condiciones, afecten el tiempo, modo o lugar en que el consumidor puede ejercer sus derechos. Para establecer la naturaleza y magnitud del desequilibrio, serán relevantes todas las condiciones particulares de la transacción particular que se analiza. Los productores y proveedores no podrán incluir cláusulas abusivas en los contratos celebrados con los consumidores. En caso de ser incluidas serán ineficaces de pleno derecho".

111 El artículo 2 del RD 1906/1999 tendiente a que en los contratos celebrados vía telefónica o electrónica puedan modificarse los clausulados, generando circunstancias más fiables de irreversibilidad (Raynouard, 2000) y dotando al consumidor de una garantía sobre la forma final del documento ${ }^{113}$.

No es ajeno lo precedente a la regulación colombiana (NEC), pese a no estar regulada la remisión en el capítulo de la contratación electrónica, el artículo $39^{114}$ aplicable a todos los contratos de adhesión que plantea, que una vez celebrado el contrato, el productor $y / o$ proveedor está obligado a la entrega de una constancia escrita y de los términos de la operación al consumidor, a más tardar, dentro de los tres días siguientes a la solicitud. La anterior norma de seguro que será objeto de un desarrollo regulatorio posterior en el ámbito de la contratación electrónica, como en su momento se hizo en el caso español (art. 3.1 del real decreto 1906/1999), y donde se realizó una equivalencia funcional (Caprioli, 1997) al escrito físico ${ }^{115}$, con cualquier soporte duradero adecuado al medio de comunicación empleado.

es necesario que conste en los términos que reglamentariamente se establezca, la aceptación de todos los clausulados contractuales, sin necesidad de firma convencional.

112 Según el artículo 5.4 LCGC: "En los casos de contratación telefónica o electrónica será necesario que consta en los términos que reglamentariamente se establezcan la aceptación de todas y cada una de las cláusulas del contrato, sin necesidad de firma convencional. En este supuesto, se enviará inmediatamente al consumidor justificación escrita de la contratación efectuada, donde constarán todos los términos de la misma".

113 Al respecto declara Pardo (2003) "si las estipulaciones o cláusulas contractuales se exponen online, nada garantiza la modificación de las mismas por parte del operador que gestiona la web en tanto que pueden resultar continuamente manipuladas, modificadas o eliminadas" (p. 59).

114 Artículo 39: "Constancia de la operación y aceptación. Cuando se celebren contratos de adhesión, el productor y/o proveedor está obligado a la entrega de constancia escrita y términos de la operación al consumidor a más tardar dentro de los tres (3) días siguientes a la solicitud. El productor deberá dejar constancia de la aceptación del adherente a las condiciones generales. El Gobierno Nacional reglamentará las condiciones bajo las cuales se deberá cumplir con lo previsto en este artículo".

115 Conforme al artículo 23.3 de la LSSICE "siempre que la ley exija que el contrato o cualquier información relacionada con el mismo conste por escrito, este requisito se entenderá satisfecho si el contrato o la información se contiene en un soporte electrónico". 
Recuérdese que el NEC plantea, además de todas las cargas informativas previas a las que hemos hecho alusión, que se requiere una forma especial para el reforzamiento del consentimiento, aplicable, justo al momento de perfeccionar el acto, al obligar al proveedor a presentar y facilitar el resumen (archivo, impresión o descarga) de la transacción.

Es evidente que en el caso de las condiciones generales de la contratación, al no poder ser negociados individualmente sus clausulados, la normativa plantea un control amplio, lo que significa en la práctica, una aceptación o rechazo total, de ahí el derecho que tengan los consumidores en cualquier etapa, a consultar y almacenar las condiciones generales. Para garantizar que antes del perfeccionamiento del contrato, el consumidor pueda leer, y analizar el contenido y el alcance de todas las obligaciones y derechos al que tendrá lugar, concediéndose la facultad de disponer del texto íntegro de las condiciones generales. Por ello es tan común, que antes de continuar con el proceso de aceptación y pago por vía electrónica (en el ámbito comunitario y siendo además una práctica cada vez más común en Colombia) el consumidor tenga que dar clic en una ventana donde se especifica que se ha leído, y por consiguiente, acepta los términos

116 En la etapa poscontractual se pueden observar también formalidades al interior del contrato electrónico, como se recordó en lo referente a que el proveedor del servicio deberá facilitar información escrita sobre las condiciones y modalidades del ejercicio de desistimiento y resolución, así como el modo y pasos para proceder (art. 3, ley 47/2002).

117 Artículo 48: "Contratos especiales. En los contratos celebrados a distancia, telefónicamente, por medios electrónicos o similares, el productor deberá dejar prueba de la aceptación del adherente a las condiciones generales".

118 Artículo 50 literal h. en su parágrafo: "El proveedor deberá establecer en el medio de comercio electrónico utilizado, un enlace visible, fácilmente identificable, que le permita al consumidor ingresar a la página de la autoridad de protección al consumidor de Colombia".

119 Interesante el caso belga, en donde existen diversos inspecteurs du contrôle des sites de commerce électronique, siendo agentes del Ministerio de Asuntos Económicos, quienes entre muchas otras funciones aplican medidas de derecho administrativo sancionador frente al no cumplimiento de la normativa de protección generales de la contratación, de lo contrario, no podrá proseguir con el proceso de compra ${ }^{116}$.

Exacta situación plantea el NEC en su artículo $48^{117}$ en lo correspondiente a que el expendedor deberá dejar prueba de la aceptación de las condiciones generales (control de incorporación), so pena de su no validez al interior del contrato; son incluso tan tuitivas sus normas que adiciona a lo precedente, que todos los expendedores que utilicen Internet para realizar sus transacciones deban incluir en su portales web un enlace visible, y fácilmente identificable a la página de la autoridad de protección al consumidor ${ }^{118}$. Obligación persuasiva pero que de nada servirá si el Estado colombiano no ajusta su estructura administrativa para un control efectivo de dichos portales ${ }^{119}$, cambios que se esperan en el ámbito del comercio electrónico y en el físico, ya que el NEC le otorga músculo financiero a la SIC (que no tenía) al hacerla beneficiaria de todas las sanciones pecuniarias que imponga ${ }^{120}$.

Como se ha visto dentro de las formalidades aludidas, el NEC reúne lo que en la doctrina se ha denominado el control de incorporación (no se tendrán como integradas al contrato aquellos clausulados predispuestos que no hayan sido aceptados $^{121}$ ), y el control de contenido (Serra,

a los consumidores, y quienes ya habían inspeccionado para el año 2001, 2.000 sitios de comercio en línea constatando que en 647 webs no se cumplía con la normatividad vigente (Droit \& Technologies, 22 de abril de 2003).

120 Así queda estipulado en diversos apartes, por citar alguno: "art. 58. Numeral 10. Si la decisión final es favorable al consumidor, la Superintendencia de Industria y Comercio y los jueces podrán imponer al productor o proveedor que no haya cumplido con sus obligaciones contractuales o legales, además de la condena que corresponda, una multa de hasta ciento cincuenta (150) salarios mínimos legales mensuales vigentes a favor de la Superintendencia de Industria y Comercio". Igual forma en el numeral 11 y el parágrafo 3 del artículo 61, la SIC, era beneficiara de diversas multas con ocasión a la violación del hábeas data, no obstante, ello se consideró como inconstitucional en la sentencia C-748/2011 de la Corte Constitucional colombiana proferida el 6 octubre de 2011, con ponencia del magistrado Jorge Ignacio Pretelt Chaljub.

121 Aplicable solo para los contratos no negociados individualmente. 
2005) frente a la legalidad de los preceptos de conformidad con la buena fe.

Cuya justificación radica en las funciones que desempeña la forma en las condiciones generales del contrato; por un lado de la prevención ${ }^{122}$ en cuanto a que la información allí ofrecida debe ser obligatoria y consagrada de una manera concreta (clara, sencilla y documentable) que permita y refuerce el análisis, estudio y reflexión que debe caracterizar la manifestación del consentimiento evitando así su precipitación. Por otra parte, de una función integradora, en la que la información suministrada, formar parte de las condiciones en cuanto al contenido del contrato a celebrar. Así, se busca que las condiciones del contrato estén predispuestas por la ley a través de la forma del contrato. Garantizando con lo anterior, que la información se produzca en unos términos inequívocos, aspecto que vamos a poder comprobar a través del documento contractual correspondiente (Martín, 2001).

Por último, su justificación se encuentra como ya lo habíamos dicho, en la función probatoria, que opera en ambas vías para los intervinientes, desde el empresario, demostrando que ha cumplido con la responsabilidad de información (cuando esta está documentada) y de aceptación y existencia de los contenidos predispuestos; y por parte del consumidor, cuando puede archivar y demostrar las reglas por las que se rige el contrato sin la incertidumbre que caracteriza la información publicada en la red.

\section{CONCLUSIONES}

El NEC es una norma que se encuentra -en términos generales- al día en lo que respecta a las obligaciones pre y poscontractuales de información en la contratación electrónica que rigen

$122 \mathrm{Y}$ es que la forma del contrato se ha revelado como vehículo informativo de un conjunto de menciones obligatorias, que son las que deben aparecer en el documento contractual. Por ello, podríamos hablar de una nueva categoría de forma esencial, pues es la forma ad solemnitatem la que desempeña de un modo más efectivo esta función. al interior de la Unión Europea; y que garantizan, por los menos, desde la teoría, el derecho que tienen los consumidores a recibir una información adecuada, clara, veraz y suficiente sobre la identidad y la actividad desarrollada por los proveedores o comercializadores de la red; los bienes o servicios que ofrecen; las consecuencias que se derivan de la contratación; la confirmación de la celebración del contrato; de su existencia; de la disponibilidad previa y posterior; de las condiciones generales cuando están presentes; del detalle de los valores finales del objeto o servicio contratado, incluyendo impuestos y cargos de entrega (cuando procede); y de la manera en que se deben ejercer los derechos de retracto contractual.

El NEC presenta múltiples puntos de conexión con la normativa europea que permiten contribuir a la construcción de las soluciones globales que deben determinar los marcos regulatorios del comercio electrónico. Pone fin a años de incertidumbre jurídica, regulando materias hasta la fecha inexistentes en el ámbito colombiano, reforzando así los derechos de los consumidores. Por tanto, queda todo servido en cabeza del poder ejecutivo y en su nombre, del Ministerio de Comercio, Industria y Turismo, para que se implemente una pronta reglamentación cuya moratoria comienza a opacar lo hecho desde el legislativo.

Por su parte, la SIC, deberá terminar su proceso de reestructuración y "desbogotanización" para hacer presencia en las regiones, y por supuesto, en el mundo virtual, en búsqueda de un cumplimiento efectivo de las normas, con miras a modificar positivamente el comportamiento de los agentes, que con la entrada en vigor de la normativa deberán adecuar sus canales de comercialización a los parámetros internacionales de control, transparencia, confianza y seguridad, en un mundo cada mes más globalizado en donde la armonización del derecho pasó de ser un ideal del espacio comunitario a trascender las órbitas internacionales. 


\section{REFERENCIAS}

Akerlof ,G. (1970). The maker of lemons. Qualitative Uncertainty and the Market mechanism. Quarterly Journal of Economics, 84, 488-500.

Alpa, G. (1981). Appunti sulla responsabilità precontrattuale nella prospettiva della comparazione giuridica. En Responsabilità civile e previdenza. Torino: Giuffrè.

Ancos, H. (2001). La protección de los consumidores en la comercialización a distancia de los servicios financieros: una perspectiva de derecho comunitario europeo. Revista de Derecho Comunitario Europeo, 5(10), 627-645.

Arias, M. (2006) . Manual Práctico de Comercio Electrónico. Madrid: La ley

Ballugera, C. (2007). Prácticas abusivas, información, integración contractual y regla "contra proferentem". Revista Aranzadi de Derecho y Nuevas Tecnologías, 14(2), 29-38.

Barceló, R. \& Montero, E. (2000). La proposition de directive européenne sur le comerse électronique : questions choisies. En Commerce électronique. Le temps des certitudes. Cahier du centre de recherches. Informatique et droit. Bruselas: Bruylant.

Barrioso, C. (1998). La contratación electrónica. Madrid: Dikynson.

Batuecas, A. (2004). Deberes de información del proveedor en la contratación electrónica. En A. Moro (dir.). Autores, consumidores y comercio electrónico. Madrid: Colex.

Boyer, Y. (1978). L'obligation de renseignements dans la formation du contrat. Marsella: PUAM. Caprioli, E. (1997). Preuve et signature dans le commerce électronique. Droit et Patrimoine, $55,56-61$.

Castañeda, J. (1992). Historia breve de la evolución de la protección a los consumidores en la CEE. Cuadernos de Estudios Empresariales, 2, 195-205.

Coase, R. (1960). The problem of social cost. Journal of Law and Economics, 3. 1-44.

Comisión Europea (1997): Comunicación de la comisión de las comunidades Europeas al Consejo, al Parlamento Europeo, al comite economico social y al comité de las regiones sobre iniciativa Europea de comercio electrónico, Bruselas, p. 7-10, 16-04-1997, COM 97; 157 final.

De Castro, F. (1965). Las condiciones generales de los contratos y la eficacia de las leyes. Madrid: Civitas ediciones.

De Mauro, A. \& Fortinguerra, F. (2002). La responsabilità precontrattuale. Padova: Cedam.

De Miguel, P. (2005). Derecho del comercio electrónico. México D. F.: Porrúa.

De Miguel, P. (2008). La tutela de los consumidores en el mercado global: evolución del marco normativo. Estudios sobre Consumo, 85, 23-44.

De Nayer, B. \& Laffineur, J. (2000). Le consentement électronique: le cadre législatif Belge. En le consentement électronique. Bruselas: Bruylant.

Demoulin, M. \& Montero, E. (2002). La conclusion des contrats par voie électronique. En le processus de formation du contrat. Bruselas: Bruylant, 693-701.

Dias, E. (2004). Tutela do consumidor na Internet. Direito da Sociedade da Informação, V.350-364.

Diez, J. (2008). Obligaciones precontractuales de información en la contratación electrónica y protección de los consumidores. Estudios sobre Consumo, 85, 74-90.

Faggella, G. (1906). Dei periodi precontrattuali e della loro vera ed escatta costruzione scientifica. En Studi giuridici in onore di Carlo fadda (tomo III) (217 y ss.). Napoli. 
Fagnart, J. (1988). La formation et l'exécution des contrats. En Collection Droit et Consommation. Louvain la Nouve: Centro de Droit de la Consommation, 24-52.

Fernández, M. (s. f.). Comercio electrónico y mundialización. Recuperado de http://www. delitosinformaticos.com/ecommerce/ globalizacion.shtml

Fin-Langer, L. (2002). L`équilibre contractual. París: LGDJ.

FTC Bureau of Consumer Protection Report. (2000, septiembre). Consumer protection in the global electronic marketplace: looking ahead. Recuperado de http://www.ftc.gov/bcp/icpw/ lookingahead/lookingahead.htm

García, E. (2004). Los negocios y la realidad jurídica de las nuevas tecnologías. En A. Moro (dir.). Autores, consumidores y comercio electrónico. Madrid: Colex.

Harsanyi, J. (1967). Bargaining in ignorance of the opponent's utility function. Journal of Conflict Resolution.

Huet, J. (1997). Aspects juridiques du commerce électronique: approche internationale. Petites Affiches, 116(27), 6-20.

Kraut, A. (1996). Información: un derecho constitutivo del hombre en sociedad. Algunos enfoques jurídicos. En $\backslash$ Kemelmajer A (Dir.) 89-110. Derecho de daños. Buenos Aires: La Roca.

Laffineur, J. (2000). Le consentement électronique: les clefs de la protection juridique du consommateur. En Le consentement électronique. Bruselas: Bruylant.

Leible, S. (2008). Mercado interior, comercio electrónico y protección del consumidor. Estudios sobre Consumo, 85, 9-22.

Llobet, J. (1996). El deber de información en la formación de los contratos. Madrid: Marcial Pons.
López, F. (2008). Introducción al derecho mercantil. Bogotá: Temis.

Malaurie, $\mathrm{P}(1987)$. "Préface" de la thése de V. Christianos, l'obligation d'informer dans la vente des produits mobiliers. Bruselas: E. Story-scientia.

Mata y Martín, R. (2001). Algunos aspectos de la delincuencia patrimonial en el comercio electrónico. En J. Echeverría (coord). El comercio electrónico. Madrid: Edisofer S. L.

Martin, M. (2001). La protección de los intereses del consumidor a través de la forma del contrato. Aranzadi Civil, 6, 1986-2005.

Mas, F. (2005). La conclusion des contrats du commerce électronique. París: LGDJ.

Monsalve, V. (2008). Consideraciones actuales sobre la obligación precontractual de información, una perspectiva europea. Vniversitas, 117, 115-152.

Monsalve, V. (2008). La buena fe como fundamento de los deberes precontractuales de conducta. Una doctrina europea en construcción. Revista de Derecho, 30, 30-74.

Monsalve, V. (2009). El comportamiento del contratante como determinación de la ruptura injustificada de las negociaciones: visión desde el derecho europeo. Vniversitas, 119, 251-278.

Monsalve, V. (2011). Dinámica de la obligación y el deber de informar (se) en la fase precontractual. La relación de consumo. Aramburo, M (Coord.).En Libro homenaje a Javier Tamayo Jaramillo, 477-520. Medellín: Diké.

Monsalve, V. \& Rodado, D. (2010). Importancia de la obligación de información en las relaciones financieras de consumo. Una aproximación económica y jurídica. Revista de Derecho, 33, 30-74.

Narváez, J. (2009). Introducción al derecho mercantil de Narváez J. Bogotá: Legis. 
Ontiveros, F. \& Mora, C. (2003). La contratación electrónica. Diario La Ley, 5730, marzo.

Orti Vallejo, A (1992). La obligación de información. En Comentarios a la ley General para la defensa de los consumidores y usuarios. Bercovitz-Cano R (coord.), Madrid: Civitas. Pag. 406 a 420

Pacheco, M. (2000). La protección del consumidor una vez perfecto el contrato en la venta de productos a distancia a través de Internet. La Ley, 5184.

Pardo, J. (2003). Las páginas web como soporte de condiciones generales de la contratación. Pamplona: Aranzadi.

Pérez, A. (1990). La información en la contratación privada. Madrid: Instituto Nacional de Consumo de España.

Pérez, C. (2001). Contratación electrónica (contratación celebrada por medios telemáticos). Aranzadi Civil, 20, 69-83.

Raynouard, A. (2000). Le concept de document contractuel appliqué au commerce électronique. En María José Reyes López, Le consentement électronique. Bruselas: Bruylant.
Reyes, M. (2005). El derecho de información. En M. Reyes (coord.). Derecho privado de consumo 180-201. Valencia: Tirant lo Blanch.

Roppo, E. (1975). Contratti standard: autonomia e controlli nella disciplina delle attività negoziali di impresa. Milán: Giuffrè.

Saleilles, R. (1901). De la déclaration de volante. Contribution á l'étude de l'acte juridique dans le code civil allemand. París: Pichon.

Santarelli, F. (2009). Ley de defensa del consumidor, comentada y anotada. Buenos Aires: La Ley.

Serra, A. (2005). Condiciones generales de la contratación y cláusulas abusivas en los contratos celebrados con consumidores. En M. Reyes (coord.). Derecho privado de consumo, 317-364. Valencia: Tirant lo Blanch.

Vila, J. (2001). Aspectos técnicos para el desarrollo de aplicaciones de comercio electrónico. En J. Gómez (dir.). Comercio electrónico en Internet. Madrid: Marcial Pons.

Weingarten, C. (2007). Derecho del consumidor. Buenos Aires: Universidad SRL.

http://www.ftc.gov/es 